\title{
Truyền thông tài chính: thông tin là tiền
}

\author{
Tác giả: TS. Vương Quân Hoàng \\ Nghiên cứu viên cao cấp \\ Bộ môn Tài chính \\ Trung tâm Emile Bernheim, ĐHTH Bruxelles \\ $\&$ \\ SAGA - www.saga.vn
}

Bài viết tham dụ̂ Hội thảo Báo chí với doanh nghiệp - Doanh nghiệp với báo chí

Tổ chức ngày 6/10/2007, tại Hà Nội.

Bài viết có sự tham gia chuẩn bị của: Trần Trí Dũng, Bùi Quang Nam, Lưu Quý Phương và SAGA.VN - Hệ thống phân tích-truyền thông kinh doanh Việt Nam

\section{Mục lục}

Mở đầu

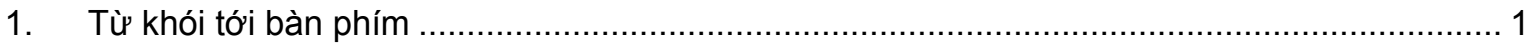

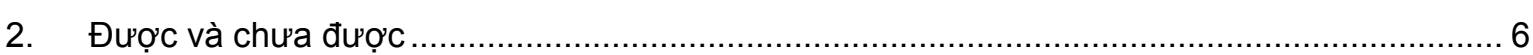

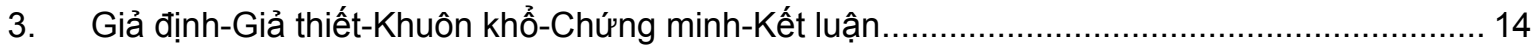

4. Truyền thông tài chính: Từ cảm xúc tới quyết định ............................................................ 19

5. Vai trò giáo dục và định hướng thông tin của báo chí trên TTCK ......................................... 21

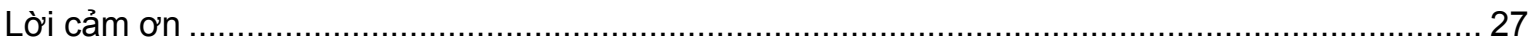

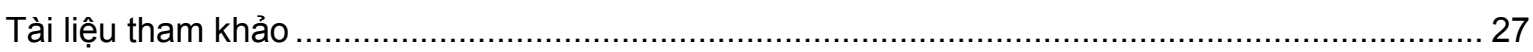

\section{Mở đầu}

Các quyết định tốt trong đầu tư ngày nay còn được gọi là: Các quyết định đầy đủ thông tin, nguyên văn tiếng Anh: "Well-informed decisions."

Truyền thông ngày càng quan trọng do đó là phương pháp hữu hiệu tác động vào tâm lý và cảm xúc xã hội, trong đó có rất nhiều doanh nhân, người làm chuyên môn và các nhà đầu tư. Xã hội có hiện tượng phân hóa rõ rệt giữa những công ty có khả năng phát triển hệ thống truyền thông tốt tới công chúng.

Trên thị trường tài chính-chứng khoán Việt Nam, truyền thông cũng có vai trò vô cùng quan trọng. Báo Đầu tư Chứng khoán được thị trường đón chờ, các báo như Tiền Phong vốn xưa nay không đặt thế mạnh vào TTCK cũng đưa ra chuyên mục này để thu hút độc giả, v.v.. Đó là bằng chứng cho thấy truyền thông được đón nhận hào hứng thế nào.

\section{Từ khói tới bàn phím}

Phát kiến ngôn ngữ: khó khăn và vĩ đại

Khói lửa được xem như một giả thiết khoa học đầu tiên về truyền thông từ khoảng cách xa. Điều ấy diễn ra trước chữ viết thô sơ khoảng 1,2 triệu năm. 
Phát kiến ngôn ngữ là hành trình dài, khó khăn và vĩ đại của loài người. Nó gắn liền với sự phát triển sản xuất, kỹ năng và tư duy của con người (Watson, 2006). Bằng chứng khảo cổ học cho thấy giống người-khôn-ngoan (Homo Sapiens) hình thành cách đây khoảng 500.000 năm đã biết ăn thịt các loài động vật như linh dương, ngựa vằn hay hà mã. Trong quá trình tìm kiếm thức ăn, người-khôn-ngoan phải chiến đấu với con mồi hoặc phải đương đầu với các loài ác thú để tranh giành xác con mồi. Thực tế này, theo các nhà cổ sinh vật học, buộc họ phải sống tập trung thành từng bầy lớn, từ 60 đến 80 thành viên. Để tập hợp hiệu quả, dứt khoát cần sự tồn tại một khả năng ngôn ngữ nhất định. Truyền thông ra đời như sự tồn vong của con người!

Người ta cũng tin rằng, những công cụ tạo tác đồ đá của loài người $\mathrm{H}$. Sapiens thời cách đây 500.000 năm đã bắt đầu phức tạp và đòi hỏi nỗ lực truyền thông. Các nhà khảo cổ nhẩm tính rằng để có được lưỡi rìu có hình thù tinh tế và công dụng gia tăng cho lao động sản xuất, cần tới 6-8 người cùng thao tác với khoảng 250 nhát đập. Như thế, không thể nào thiếu một quá trình truyền thông hiệu quả giữa nhóm người tiền sử này, nếu không muốn người này lấy đá phang vào tay người kia. Truyền thông là phương tiện đạt tới tính hiệu quả!

Dấu tích 200.000 năm trước được tìm thấy tại Siberia chứng tỏ sự tồn tại của lửa và quần áo để chống chọi với khí hậu lạnh khắc nghiệt. Để chống chọi với giá rét, người tiền sử không chỉ cần quần áo mà còn cần cả cách thức hiệu quả để bảo vệ và duy trì lửa. Và để làm được, chắc chắn họ cần tới một ngôn ngữ để trao đổi.

Một bằng chứng khảo cổ học quan trọng liên quan tới nguồn gốc của chữ viết là "nhánh gạc hươu La Marche," được phát hiện trong hang động La Marche năm 1938. Trên nhánh gạc này có chạm trổ hai con ngựa với một số hàng biểu tượng ở bên trên. Alexander Marsheck, năm 1972, phân tích và kết luận đây là một bản ghi chép các ký hiệu về mặt trăng được thực hiện trong bảy tháng rưỡi.

Sang thập kỷ 1990, Frances d'Errico tìm hiểu lại nhánh gạc này với kính phóng đại cực mạnh để xem xét các vết khía và kết luận các vết khắc được làm trong cùng một thời gian chứ không phải trong suốt bảy tháng. Tuy không chắc chắn về ý nghĩa của các ký hiệu nhưng d'Errico nhấn mạnh chúng không khác mấy các vết khía được sử dụng trong các chữ hình nêm (xem Hình 1)- bắt nguồn từ phương thức ghi chép các giao dịch thương mại. Bởi vậy, d'Errico gợi ý "nhánh gạc hươu La Marche" có thể được ghi nhận với ý nghĩa như một bản chữ viết nguyên thủy ghi chép giao dịch mua bán của người tiền sử. Một kết luận rất đáng chú ý. Truyền thông có động lực quan trọng là kinh doanh!

Nhà sử học H.W.F. Saggs ${ }^{1}$ cho rằng "không phát minh nào quan trọng với tiến bộ của con người bằng chữ viết" còn Petr Charvat ${ }^{2}$ thì gọi đây là "phát minh của phát minh." Nguồn gốc của chữ viết là vấn đề gây ra rất nhiều tranh cãi. Các giả thiết quan trọng được đặt ra. Trong nhiều năm, bản ghi trên chữ hình nêm của Mesopotamia, vùng đất được xem như một nôi văn minh của nhân loại nằm giữa hai con sông Tigris và Euphrates, được coi là chữ viết đầu tiên. Tuy vậy, giả thiết này gặp phải một vấn đề. Chữ hình nêm gồm nhiều biểu tượng rút gọn trong khi nhiều nhà khoa học

\footnotetext{
${ }^{1}$ Herry William Frederick Saggs (1920-2005), nhà sử học và Đông phương học nổi tiếng, người Anh.

2 Petr Charvat, tác giả cuốn “Mesopotamia Before History”, NXB Routledge
} 
tin rằng chữ viết thích hợp phải có liên hệ mạnh mẽ với hình vẽ hoặc biểu tượng. Đây là điểm để công trình của nhà khảo cổ học Denise Schmandt-Besserat bắt đầu.

Hình 1. Chữ tượng hình Babylon

\begin{tabular}{|c|c|c|c|c|}
\hline $\begin{array}{l}\text { Late Uruk } \\
\text { Period } \\
\text { ca. } 3100 \\
\end{array}$ & $\begin{array}{l}\text { Jamdet Nasr } \\
\text { Period } \\
\text { ca. } 3000 \\
\end{array}$ & $\begin{array}{l}\text { Early Dyn. II } \\
\text { Period } \\
\text { ca. } 2400\end{array}$ & $\begin{array}{l}\text { Ur III } \\
\text { Period } \\
\text { ca. } 2000\end{array}$ & Meaning \\
\hline en & 14 & $I-1$ & $y$ & SAG 'Head' \\
\hline$D$ & $D$ & (1) & 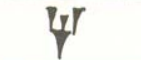 & NINDA 'Bread' \\
\hline 08 & (IDI) & 或些 & $\$ 4$ & KU 'to eat' \\
\hline & & $F$ & & $A B$ 'Cow' \\
\hline$D$ & $D$ & D & I & 1 ' \\
\hline
\end{tabular}

Nguồn: Hans J. Nissen, $1988^{3}$

Cuối thập kỷ 1960, bà được biết hàng nghìn "đồ dùng bằng đất sét" được tìm thấy ở vùng Cận Đông nhưng phần đông giới khảo cổ đã cho rằng chúng không quan trọng. Schmandt-Besserat lại cho rằng đó có thể là một hệ thống bằng chứng cổ đại bị bỏ qua. Do vậy, bà bắt đầu tìm hiểu hàng loạt dấu hiệu kiểu này được lưu giữ tại Cận Đông, nam châu Phi, châu Âu và châu Mỹ. Càng tìm hiểu càng phát hiện nhiều điểm thú vị. Các dấu hiệu này, dù mang ý nghĩa gì, không hề tầm thường. Thậm chí, bà còn tìm được một tấm thẻ tại Nuzi, một địa điểm phía Nam Iraq có niên đại khoảng thế kỷ thứ 2 trước Công nguyên. Chữ viết tượng hình trên bản khắc ghi lại thông điệp miêu tả số thẻ của một nhóm gia súc "21 con cừu cái còn non, 6 con cừu cái, 8 con cừu đực đã trưởng thành..." Và khi khai quật một hố sâu ở cạnh đó, ngưởi ta đếm được chính xác số gia súc được ghi lại. Trong 15 năm tiếp theo Schmandt-Besserat tiếp tục nghiên cứu hơn 10.000 dấu hiệu tương tự và đi tới kết luận chúng là tập hợp một hệ thống kế toán sơ khởi ghi chép việc giao dịchkinh doanh và trao đổi thương mại. Từ ngữ, trong một nghĩa nào đó, bắt đầu từ các con số. Cuối cùng, sau tất cả, chữ viết, một dạng thức của truyền thông, cho phép các bên có thể trao đổi hàng hóa và thông tin với thời gian, không gian tách biệt.

Một hành trình dài dường như ẩn chứa sợi dây liên hệ vô hình giữa phát kiến ngôn ngữ và chữ viết với các hoạt động trao đổi và giao thương (Hoàng, 2007). Dù còn nhiều ý kiến khác nhau, kết quả nghiên cứu của Schmandt-Besserat vẫn rất thuyết phục: chữ viết ra đời bắt nguồn từ nhu cầu ghi chép trao đổi và truyền thông kinh doanh.

Con đường phát kiến ra chữ viết của nhân loại trên thực tế còn gian nan hơn rất nhiều những gì vừa trình bày. Trân trọng giá trị truyền thông hiện đại là nhiệm vụ của mỗi người, trước tiên và trên hết là của người làm nghề truyền thông.

Internet và sự cộng hưởng

\footnotetext{
${ }^{3}$ Hans J. Nissen, 1998. Lịch sử nguyên thủy vùng Cận Đông: 9.000-2.000 BC, dịch sang tiếng Anh: Elizabeth Lutzeier và Kenneth j. Northcott. Đại học Chicago)
} 
Bước sang thế kỷ 21, Internet trở thành một phần thiết yếu của cuộc sống, đặc biệt với đội ngũ nhân viên văn phòng, cán bộ chuyên môn, quản lý và lãnh đạo kinh doanh. Ra đời ngày 6/8/1991, Internet nhanh chóng trở thành công cụ truyền thông quan trọng của con người. Từ chỗ hoàn toàn xa lạ với các khái niệm giao thức, trình duyệt, cơ sở dữ liệu, trực tuyến v.v.. loài người văn minh mau chóng thích thú với sự tiện lợi mà Internet mang lại trong lưu trữ, trao đổi và tìm kiếm thông tin. Internet là một thư viện khổng lồ, một trường đại học vĩ đại...

Thomas Friedman, một nhà báo- một trong những tầng lớp chịu tác động rất lớn của Internet, còn coi Internet như một sức mạnh to lớn có khả năng san phẳng mọi cách biệt về không gian, thời gian và cả tri thức hiểu biết, mang lại cơ hội công bằng cho bất kỳ cá nhân nào trên hành tinh.

Internet thậm chí còn tác động chi phối tới nhiều khía cạnh trong đời sống con người. Đơn cử một ví dụ thực tế. Những ngày tuyến cáp quang Internet châu Á bị đứt đầu năm 2007, do động đất, rất nhiều máy tính trở thành đồ vật thừa khi không kết nối được Internet. Nhiều hoạt động trao đổi thông tin trong cuộc sống, đặc biệt là truyền thông kinh doanh bị ngừng trệ. Thiệt hại kinh tế của sự cố này không hề nhỏ. Riêng hãng viễn thông lớn nhất Đài Loan Chunghwa Telecom đã phải bỏ ra 1,5 triệu USD để sửa chữa hệ thống cáp và mất đi khoản doanh thu tới 100 triệu USD trong khoảng thời gian hai tuần.

Sự xuất hiện của Internet, tiếp theo là các báo mạng (báo điện tử) có thể xem như "một cú sốc" với hệ thống truyền thông truyền thống như báo in, truyền hình và truyền thanh. Tác giả Đoàn Khắc Xuyên trên thời báo Kinh tế Sài Gòn, số tháng 9/2007, đã ghi nhận thực trạng và xu thế chuyển dịch để thích nghi với thay đổi sở thích của công chúng của cả báo in và báo điện tử tại Hoa Kỳ. Trước thực tế, các tính năng tiện dụng và dễ dàng tiếp cận thông tin của Internet, ngày càng có nhiều người từ bỏ thói quen đọc báo in và thay vào đó là lướt web để cập nhật tin tức. Điều này thực sự là một thách thức với giới báo in, mặc dù, vẫn có những quan điểm cho rằng báo điện tử đã "giải cứu" báo in trước sự tấn công của truyền hình hay điện ảnh.

Giải pháp hợp lý và hiệu quả với các báo in chính là: cắt giảm chi phí làm báo in và chia sẻ nguồn lực để phát triển hiện diện trên Internet. New York Times, tờ báo uy tín hàng đầu nước Mỹ và luôn muốn duy trì hình ảnh vốn có của mình, đã chấp nhận giải pháp cắt giảm chi phí bằng việc thu hẹp khổ (bề ngang) của tờ báo từ tháng 8/2007. Trước đó rất lâu, Wall Street Journal- tờ báo kinh tế hàng đầu nước Mỹ, cũng đã thực hiện giải pháp này. Áp lực chi phí còn buộc một số tờ báo phải cắt giảm đội ngũ phóng viên và thu hẹp nội dung. Tờ San Fransico Chronicle vào khoảng giữa năm 2007 đã thông báo giảm bớt 25\% nhân viên. 
Hướng đi tăng cường hiện diện trên Internet hứa hẹn tương lai tốt đẹp với các báo truyền thống. Với những thay đổi đa dạng nội dung và cung cấp miễn phí thông tin nhằm thu hút số lượng đông đảo và đa dạng người sử dụng thường xuyên, các báo mạng đã tìm được nguồn thu từ dịch vụ quảng cáo trực tuyến. Các hình thức dịch vụ giá trị gia tăng khác chắc chắn còn tiếp tục được đẩy mạnh phát triển và khai thác.

Báo giới Việt Nam cũng không vượt ra ngoài xu thế này. Ngoài những báo điện tử "chính thống" như VnExpress, Báo điện tử Đảng cộng sản Việt Nam, phần đông các báo in đều đã, đang và sẽ nỗ lực đẩy mạnh hoạt động trên Internet của mình. Những báo in có số lượng phát hành lớn lại đang làm rất tốt công việc này, có thể kể tới: Tuổi trẻ Online, Thanh Niên Online, Tiền phong Online, Hà Nội Mới Online, các báo điện tử Quân đội nhân dân, An ninh thế giới, Lao động, Người lao động v.v.. Mới gần đây An ninh thủ đô, Đầu tư Chứng khoán cũng đưa báo mình "lên mạng." Danh sách này, không nghi ngờ gì, còn tiếp tục kéo dài.

Bên cạnh tính sử dụng tiện lợi, dễ dàng tiếp cận, tìm kiếm, trao đổi-phản hồi, Internet còn sở hữu một ưu thế rất quan trọng so với các phương tiện truyền thông quen thuộc khác: hiệu ứng cộng hưởng. Hiệu ứng này có thể lý giải theo hai cách. Thứ nhất, sức lan tỏa thông tin trên Internet cực nhanh. Những câu chuyện dở khóc dở cười khi gửi thư điện tử nhầm địa chỉ, hay các vụ việc ầm ĩ của những nhân vật nổi tiếng khi thông tin đời tư bị tiết lộ và phát tán.. là minh chứng rất rõ ràng. Thứ hai, tác động đồng thời của hình ảnh, âm thanh, không gian và thời gian. Công nghệ Internet cho phép tạo ra các tác động nhiều chiều, đa phương tiện tới đối tượng tiếp nhận thông tin. Chính ưu thế này cùng với tính linh hoạt về chi phí dịch vụ mang lại đảm bảo vững chắc cho tương lai phát triển của lĩnh vực truyền thông trực tuyến.

Khi Rupert Murdoch trả 5,6 tỷ USD để nắm quyền kiểm soát Dow Jones- chủ sở hữu Wall Street Journal, lý giải cho quyết định này, người ta thường chú ý tới uy tín và số lượng phát hành 1,7 triệu bản mỗi ngày của WSJ. Vậy còn hiệu ứng cộng hưởng của Internet đã có tác động thế nào tới quyết định giành quyền sở hữu Dow Jones và WSJ của Rupert Murdoch? Không khó để nhận thấy newscorp.com được biết đến ở mức quá khiêm tốn so với danh tiếng của nó. Trang web này được Alexa xếp hạng thứ 125.252 thế giới vào ngày 4/10/2007. Trong khi đó, wsj.com trang trực tuyến của WSJ đứng ở vị trí thứ 1.098 thế giới. Trang web này cũng có tới 930 ngàn độc giả thuê bao sử dụng.

Yahoo! Finance và Google! Finance

Không chỉ dừng lại ở dịch vụ sản xuất và cung cấp tin tức truyền thống, Internet còn mang đến nhiều cơ hội kinh doanh thông tin, đặc biệt trong lĩnh vực tài chính và chứng khoán. Người tham gia công việc kinh doanh, đầu tư có nhu cầu rất lớn được bổ sung và cập nhật kiến thức trong lĩnh vực đang quan tâm. Bên cạnh đó, nhu cầu tiếp cận các đánh giá, phân tích, nhận định từ nhiều góc độ khác nhau với một chủ đề ngày một nhiều. Đặc trưng này càng thể hiện rõ trong hoạt động tài chính-đầu tư. Các nhà đầu tư không bao giờ chấp nhận rủi ro bỏ sót thông tin cho dù đó có thể là một thông tin không đáng giá. 
Tồn tại thực tế của nhu cầu được phản ánh qua nguồn "cung" rất dồi dào từ những "đại gia" thông tin trực tuyến. MSN, Yahoo và ngay cả Google đều không bỏ qua phần thị trường vô cùng tiềm năng này. $2 \%$ người truy cập hệ thống Yahoo với mục đích sử dụng và khai thác thông tin về tài chính và chứng khoán. Con số này có ấn tượng hơn khi chúng ta biết rằng $48 \%$ người sử dụng Yahoo chỉ để khai thác chức năng Email và Chat. ${ }^{4}$

Phát triển các hệ thống trực tuyến cung cấp nội dung phục vụ cộng đồng kinh doanh, đầu tư là hướng đi hứa hẹn thành công tương lai với một nền kinh tế đang phát triển mau chóng như Việt Nam. Đáp ứng nhanh chóng nhu cầu thông tin chưa đủ. Đây chính là nguyên nhân của hiện tượng ra đời, tăng trưởng trong thời gian ngắn, rồi thoái trào của nhiều website chuyên về chứng khoán trong thời gian khoảng 2 năm trở lại đây (Dũng, 2007). Hệ thống thông tin kinh doanh muốn phát triển lâu dài cần đảm bảo tính độc lập, khách quan, cân bằng quyền lợi trong phân tích, nhận định; độ sâu và rộng của kiến thức và khái niệm kinh tế-kinh doanh liên tục được bổ sung và cập nhật; và định hướng tốt quan tâm của người sử dụng hướng tới tương lai tươi sáng, xây dựng tích cực, đóng góp xây dựng cộng đồng, đất nước.

\section{2. Được và chưa được}

Dư âm từ các đợt sốt giá cổ phiếu và dư luận xã hội gần đây về TTCKVN thực sự liên quan mật thiết tới hệ thống truyền thông tài chính ở Việt Nam. Chúng ta không thể phủ nhận tác động của truyền thông tới thị trường tài chính và đặc biệt là thị trường chứng khoán. Với những thị trường đã phát triển, tác động của truyền thông và báo giới đương nhiên rất được quan tâm nghiên cứu.

Vai trò quan trọng của truyền thông trên thế giới

Như đã nói từ đầu, các quyết định đầu tư ngày nay còn được gọi là: Các quyết định đầy đủ thông tin. Các hãng thông tấn luôn tìm cách tấn công vào mảnh đất tài chính giàu có. Xin đưa một vài ví dụ cụ thể như sau.

Trên tờ International Herald Tribune có rất nhiều trang kẹp ở giữa (khá giống trang quảng cáo của Tuổi Trẻ) nhưng hoàn toàn chỉ công bố giá và chi tiết giao dịch cổ phiếu, trái phiếu, phái sinh, tiền tệ-ngoại hối, vàng, v.v..

Ngày nay các tin tức tài chính từ Dow Jones, Associated Press, WSJ, Investor's Daily, the Motley Fool, Factiva, v.v.. được xem là đồng nghĩa với: (i) Khách quan; (ii) Chất lượng; (iii) Cân bằng quyền lợi; (iv) Có phương pháp hợp lý. Điều đó nói rằng vì sao mà các nhà đầu tư quốc tế luôn xem xét đến các nguồn tin này trước khi quyết định.

Xét cho cùng, giá trị và vai trò của truyền thông nằm ở chất lượng của thông tin và tính khách quan. Để đảm bảo tính khách quan, tôi xin cung cấp một qui tắc sau đây của Dow Jones. Các phóng viên của Dow Jones trên toàn thế giới không được phép sở hữu cổ phiếu ở những thị trường liên quan nơi họ đưa tin. Đây là một bằng chứng của văn minh trong truyền thông tài chính.

${ }^{4}$ Thống kê Alexa.com ngày 4/10/2007 
Trong nghiên cứu chờ đăng tải trên Journal of Finance, Paul C. Tetlock đã thực hiện một công trình nghiên cứu rất công phu về tác động tự nhiên của truyền thông tới biến động hàng ngày của thị trường chứng khoán và kết luận nội dung của các tin bài về thị trường chứng khoán có những mối liên quan tới vấn đề tâm lý học và xã hội học với cộng đồng đầu tư.

Phân tích trực tiếp nội dung trong cột thông tin biến động thị trường cung cấp trên tờ Wall Street Journal (WSJ), dữ liệu được Tetlock thu thập trong 16 năm từ 1984 đến 1999. Lý do lựa chọn thông tin trên WSJ, cũng giống như những lý do đã trình bày ở trên, theo Tetlock là vì:

1. Thứ nhất, WSJ có lượng độc giả đông nhất - khoảng 2 triệu độc giả, bản báo điện tử thường được gửi đến 325.000 chuyên gia tài chính và đầu tư;

2. Thứ hai, đây là tờ báo có chất lượng và danh tiếng hàng đầu;

3. Thứ ba, dữ liệu trên báo có thể được truy cập lại trong khoảng thời gian dài.

Nghiên cứu của Tetlock, coi mức độ bi quan trong thông tin truyền thông là một biến trung gian, đã đưa ra ba kết luận hết sức thú vị. Trước tiên, Tetlock cho rằng mức độ tiêu cực (bi quan) cao trong thông tin truyền thông góp phần rất mạnh dự báo trước áp lực sẽ làm giảm giá chứng khoán, tiếp theo đó sẽ là hiệu ứng đưa giá trở về mức cân bằng cơ bản. Thứ hai, những mức bi quan cao hoặc thấp bất thường trong thông tin truyền thông sẽ góp phần báo trước cho những phiên giao dịch với khối lượng khớp lệnh lớn. Thứ ba, lợi suất thu về trên thị trường thấp sẽ tác đông nâng cao mức bi quan trong truyền thông.

Trước Tetlock cũng đã có những nghiên cứu khác trên thế giới về tác động qua lại giữa truyền thông và biến động của thị trường chứng khoán. Theo nghiên cứu của Antweiler, Wener và Murray Z. Frank, đăng trên Journal of Finance năm 2004, trong các khu vực trao đổi tự do trên Internet (chat room, forum,...) tập trung vào cổ phiếu, chứng khoán, nếu gán đặc trưng các ý trao đổi tại đây theo một trong ba tín hiệu mua, bán hoặc giữ thì xác nhận có một mối liên hệ giữa hoạt động trao đổi tại các khu vực này với khối lượng giao dịch và chỉ số độ bất ổn trong lợi suất đầu tư.

Nghiên cứu của Campbell, Grossman và Wang năm 1993 cũng giải thích tương quan giữa mức độ bi quan truyền thông tới khối lượng giao dịch. Nếu giả định giá trị trung bình của mức độ bi quan truyền thông là bằng 0 thì nếu như mức độ bi quan truyền thông cao sẽ đồng nghĩa với một lượng lớn nhà đầu tư quyết định mua hoặc bán cổ phiếu. Những nhà tạo lập thị trường khi đó sẽ buộc phải thu nhận hết lượng cổ phiếu bán ra nhằm làm bình ổn giá, điều này tạo ra khối lượng giao dịch lớn. Nghiên cứu của DeLong (1990) cũng đưa ra kết luận về mối liên hệ giữa hành vi của nhà đầu tư với mức độ cao thấp trong cảm xúc truyền thông.

Như thế, ở những quốc gia có thị trường tài chính phát triển cao cấp thì lượng quan tâm dành cho nghiên cứu về mối liên hệ giữa truyền thông với thị trường tài chính nói chung và thị trường chứng khoán nói riêng cũng rất lớn. Nói gọn lại, đó chính là vấn đề truyền thông tài chính đang được trao đổi. 
Trước hết cần khẳng định truyền thông ở Việt Nam cũng vô cùng quan trọng. Biểu hiện của tầm quan trọng này là sự lên ngôi của những tờ báo kinh doanh - tài chính - đầu tư, cả báo điện tử và báo giấy. Báo Đầu tư Chứng khoán đang có lượng độc giả theo dõi thường xuyên rất lớn. Các báo như Lao động, Tiền Phong, Hà Nội Mới,... vốn xưa nay không đặt thế mạnh vào TTCK cũng đã dành đất cho phần tin bài tài chính - chứng khoán. Ta khó tìm thấy một website có tính chất đưa tin nào mà lại không có chuyên mục tin chứng khoán. Các kênh truyền hình cũng nhất loạt đẩy ra những chương trình với tính chất tương tự, điểm qua như InfoTV của truyền hình cáp hay Bản tin tài chính của VTV.

Chỉ trong một thời gian không dài, giới truyền thông đã có những bước điều chỉnh mau chóng. Tác động của giới truyền thông tới doanh nghiệp, hoạt động tài chính và cụ thể là thị trường chứng khoán đang rõ rệt và mạnh hơn bao giờ hết. Truyền thông chính thống, bao gồm các đơn vị báo chí, các website thông tin, phân tích chuyên môn có đăng ký đã và đang trở thành nguồn tham khảo khách quan, tin cậy. Thời gian gần đây, số lượng các kênh truyền thông tài chính - kinh doanh phi chính thống cũng tăng rất nhanh, đóng vai trò không nhỏ trong việc định hình tâm lý và tác động vào hành vi của công chúng. Chưa bao giờ sức nóng truyền thông tài chính trên quy mô rộng, trải đều trên mọi khía cạnh, tần suất cao và có chiều sâu có thể cảm nhận rõ như giai đoạn 2 năm (2006-2007) gần đây.

Ta vừa nói tới những cái được của truyền thông tài chính. Ở phía bên kia, cũng có những cái chưa được cần chỉ rõ. Giá chứng khoán có thể tăng giảm theo các dòng thông tin. Nhưng việc tăng giảm này chỉ đồng nghĩa với "xác lập được điểm cân bằng" $\mathrm{KHI}$ VÀ $\mathrm{CHI}$ KHI các qui tắc văn minh được đảm bảo. Đây lại là yêu cầu mà chưa hẳn tất cả các đơn vị truyền thông, các phóng viên đều đảm bảo hoặc đã nỗ lực đủ lớn để hoàn thành.

\section{Một số hạn chế của thông tin tài chính ở Việt Nam}

Trước tiên phải nói tới lượng thông tin mà cơ quan truyền thông có để xử lý. Cán cân đóng vai trò quan trọng trong việc thiết lập "cân bằng thông tin." Nó là cái gì vậy? Nó là qui tắc quan trọng của tiêu chí truyền thông văn minh mà chúng ta dễ hình dung như là "nghe bằng hai tai." Hễ thấy một điều có vẻ hay hay mà tin ngay thì chưa hợp lý. Hoặc mang sẵn một thiên kiến để đưa ra một mẩu tin thì sẽ càng khó chấp nhận hơn.

Điều gì xảy ra nếu phóng viên đang nắm một lượng cổ phiếu của Công ty A-Stock?? Liệu người viết đó có thể cân bằng lợi ích khi A-Stock gặp phải một tin bất lợi cho giá cổ phiếu hay không? Hẳn mọi người đã tự có câu trả lời.

Điều thứ hai đáng nói là trình độ xử lý tin. Có biết bao nhiêu yếu tố giúp thị trường đạt tới đồng thuận về giá. Nếu mẩu tin được xử lý khoa học, cân bằng và có phương pháp, nó đáng tin cậy. Nhưng nếu nó được ra đời từ một hệ tư duy thiên lệch thì quả là thảm họa. Kỹ thuật lật ngược và 
phản biện có vai trò quyết định trong việc tạo ra mẩu tin chất lượng cao. Điều này không biết bao nhiêu người muốn "phân tích" thực sự trau dồi kỹ năng. Phần sau sẽ quay lại trao đổi sâu hơn, nhưng cần khẳng định đây là dạng kỹ năng cao cấp, rất cần thời gian và nỗ lực để rèn luyện. Rất ít người đã có sã̃n kỹ năng này từ đầu.

Thứ ba nữa là bối cảnh. Một lượng đông người đồng ý đã hẳn là số đông đó đúng? Nói như vậy không có ý rằng số đông là không tốt, nhưng không khí huyên náo và ồn ào tác động rất mạnh tới sự tỉnh táo của một cá nhân cụ thể đứng trong đó. Quá nhiều và quá nhiều lời nói hay, tán dương, sẽ khiến cho từng cá nhân hào hứng tới mức độ khó tin, đẩy mạnh kỳ vọng hơn nữa về tăng trưởng. Một hiệu ứng tâm lý không thể bỏ qua.

Công bằng thông tin thấp. Đây là điều cực kỳ đáng trăn trở ở Việt Nam. "When Alan Greenspan speaks" là một ví dụ. Greenspan là một tượng đài tài chính thế giới ngay cả sau khi ông đã xin nghỉ hưu thành công khỏi chức vụ Chủ tịch FED Fund đầy quyền lực của Hoa Kỳ. Luật của ông về thông tin là im lặng tuyệt đối. Khi nói ra là cùng một lúc trước hàng trăm ống kính. Đó là sự công bằng thông tin tài chính. Điều này cũng được các công ty niêm yết và các doanh nghiệp hướng tới sự công bằng-văn minh thực hiện theo.

Tuy thế, tính công bằng này ở các doanh nghiệp và cả hệ thống môi giới Việt Nam đang là điểm hạn chế. Lợi nhuận ở một góc độ nào đó, trở thành lực cản kìm hãm sự công bằng. Trong ngắn hạn, một số sẽ thu về lượng tiền lớn. Nhưng về dài hạn, điều đó sẽ có thể ảnh hưởng tiêu cực tới một TTCKVN đang lên. Tại sao vậy? Có ai muốn mình là kẻ thiệt thòi trong một xê-ri đầu tư luôn thất bại không? Điều gì xảy ra nếu sự thất bại của bản thân người đó là do bị khống chế và "tiếp cận nhầm" phải các thông tin không trung thực, qua các lăng kính mang màu sắc tranh chấp quyền lợi?

Rõ ràng thông tin là một giá trị, và quyền sở hữu, quyền ngăn chặn người khác tiếp cận thông tin chính xác đã trở thành một dạng quyền lực có sức mạnh rất lớn. Các sách quản trị hiện đại có phân tích về hệ thống quyền lực đã đưa "Quyền lực thông tin" trở thành một trong các quyền rất quan trọng. Nhà đầu tư trên TTCKVN cũng cần biết tới điều này mà lọc thông tin cho chính xác, cẩn trọng và đúng với kỳ vọng được thiết lập cho riêng mình.

Khi nào vắng bóng những nguồn tin tốt, theo nghĩa đủ, công bằng, và có chất lượng phương pháp tin cậy, tin đồn sẽ tung hoành và các nhà đầu tư sẽ trôi dạt giữa các hệ thống tin đồn.

Người giúp mang lại sự công bằng đó không ai tốt hơn các phóng viên nghiêm túc.

Vậy có thể làm gì?

Phía trên có nhắc đến việc những đơn vị truyền thông như Dow Jones, Associated Press, WSJ, Investor's Daily, the Motley Fool, Factiva, v.v.. được các nhà đầu tư quốc tế tham khảo rất kỹ trước khi ra quyết định. Ngoài các đặc tính như khách quan; chất lượng; cân bằng quyền lợi; và có 
phương pháp hợp lý thì cũng cần phải nói bản thân những đơn vị này vừa tự có uy tín và năng lực chuyên môn, vừa có chung đặc tính là gắn với những tên tuổi hàng đầu trong lĩnh vực chuyên môn tài chính, kinh doanh. Chẳng hạn như Charles Dow với Dow Jones hay William O'Neil với Investor's Daily.

Không thể phủ nhận vai trò của cá nhân trong truyền thông, mà đặc biệt là truyền thông tài chính kinh doanh. Lý do là ngoài nhóm tin tức thuần túy, nhóm bài phân tích chuyên sâu, dự báo, đánh giá, bình luận là những bài rất được quan tâm. Ở trên đã nói đến cách Alan Greenspan khi còn đương chức tại FED đã làm để đảm bảo tính công bằng thông tin, lý do đơn giản bởi những đánh giá, bình luận, dự báo của ông được tin cậy. Ngay cả khi ông đã về hưu, mỗi khi có sự kiện nóng, cần xin ý kiến, thì phát biểu của Greenspan khi được phỏng vấn vẫn được Bloomberg hay $\mathrm{CNN}$ chạy rất rõ trên màn hình: "Greenspan says:..." Khi tất cả đồng ý rằng một điều sẽ xảy ra, nhất là trên thị trường tài chính, thì khả năng xảy ra trên thực tế hầu như là chắc chắn.

Để có những đánh giá, nhận định hay dự báo có giá trị, bản thân người sản xuất ra thông tin đó hoặc phải tự có hoặc phải tìm được nguồn có thể cung cấp với khả năng thống kê và phân tích thống kê tốt. Thống kê là một phần không thể thiếu của kinh doanh và phần nhiều sinh ra, mở rộng là để phục vụ hoạt động kinh doanh. Dữ liệu thống kê và kĩ năng phân tích số liệu thống kê đang là hạn chế chung của các đơn vị làm truyền thông.

Hồi năm 2000, trong lúc loay hoay tìm hướng nghiên cứu, tôi quyết định cùng một người bạn thử các hướng về tỷ giá hối đoái. Chúng tôi nhận thấy cần tìm dữ liệu tỷ giá hối đoái theo ngày. Các dữ liệu này không hề được lưu trữ ở dạng điện tử, có chăng thì là các tệp tin (file) MS Word hoặc Excel nhỏ xíu, thông tin sơ sài theo tháng hay năm. Nguồn duy nhất có thể cứu vãn là báo giấy. Cho dù phải khổ công nhập lại hàng ngàn điểm dữ liệu, chúng tôi cũng sẵn lòng. Vấn đề nằm ở chỗ tìm lưu trữ ở đâu bây giờ? Có một nơi đáng tin cậy lưu giữ số liệu này ở dạng giấy in.

Chúng tôi cất công liên hệ và nhận được tin khá buồn. Nhiều bọc báo lưu trữ đã bị... mối xông! Mãi sau đó chúng tôi cũng có số liệu cần thiết. Cũng có một vài kết quả nghiên cứu có ý nghĩa. Trong một thời gian dài, chúng tôi còn sử dụng phương pháp ARIMA và số liệu đó để cung cấp các dự báo tỷ giá hối đoái cho Thời báo Kinh tế Sài gòn và Thời báo Kinh tế Việt Nam. Cùng với HSBC (5\%), Deutsche Bank AG Vietnam (4-4,5\%), chúng tôi là nguồn duy nhất đưa ra con số dự báo tốc độ trượt giá của tiền đồng so với đô la Mỹ trong năm 2002 sẽ là 2,7\% dựa trên chuỗi tỷ giá kể từ năm 1989 tới hết năm 2001 (Thục Đoan, 2002). Cuối năm này, chúng tôi cũng trình bày bảng dự báo tỷ giá các tháng của năm 2003 (Thục Đoan, 2002b). Khi so lại với thực tế, độ lệch cũng không đáng kể.

Điều đáng nói là việc tính toán dự báo này được tiến hành khi hầu hết giới chuyên gia và công chúng tin rằng giá USD sẽ tăng lên 18.000 đến 20.000 VND/USD vào thời điểm cuối năm. Như vậy nếu cứ nghe theo điều mà báo giới hay dư luận chung đang đồng ý, việc dự báo một mức trung bình trên 18.000 VND/USD sẽ được rất nhiều người vỗ tay. Tuy nhiên khi sử dụng các phương 
pháp thống kê và phân tích, xử lý dữ liệu thống kê, kết quả cho thấy mức độ trượt giá chỉ xấp xỉ $3 \%$ tức là chỉ gần sát đến mức 16.000 VND/USD. Đó là câu chuyện năm 2003, thực tế ở thời điểm hiện tại đã chứng minh một phương pháp khoa học có căn cứ mang lại kêt quả có tính chính xác cao. Như thế báo giới, truyền thông, chuyên gia, dư luận chỉ là một nửa câu chuyện, nửa kia cần có óc phân tích và phương pháp thích hợp. Nói cách khác, cần có sự phối hợp giữa đơn vị có khả năng định hướng thị trường và nguồn thông tin chuyên môn, khách quan, uy tín. Rõ ràng thừa thông tin nhưng thiếu phương pháp cũng sẽ rất nguy hiểm.

\begin{tabular}{cccccc}
\multicolumn{6}{c}{ So sánh số dự báo và thực tế tỷ giá } \\
\hline \multirow{2}{*}{ Tháng } & \multirow{2}{*}{ Dụ̂ báo } & \multicolumn{5}{c}{ Tỷ giá thực tế* } & $\begin{array}{c}\text { Lệ́ch } \\
\text { tuyệt đối }\end{array}$ \\
\hline 1 & 15599 & 15395 & 15418 & 15407 & 192 \\
2 & 15601 & 15415 & 15441 & 15428 & 173 \\
3 & 15647 & 15415 & 15443 & 15429 & 218 \\
4 & 15809 & 15400 & 15467 & 15434 & 375 \\
5 & 15840 & 15445 & 15470 & 15458 & 382 \\
6 & 15929 & 15465 & 15489 & 15477 & 452 \\
7 & 15650 & 15490 & 15513 & 15502 & 148 \\
8 & 15643 & 15495 & 15521 & 15508 & 135 \\
9 & 15614 & 15510 & 15538 & 15524 & 90 \\
10 & 15642 & 15545 & 15572 & 15559 & 84 \\
11 & 15821 & 15620 & 15646 & 15633 & 188 \\
12 & 15967 & 15625 & 15648 & 15637 & 331 \\
\hline \hline
\end{tabular}

(*): Ngân hàng Ngoại thương Việt Nam

Dự báo luôn là dự báo, không có vấn đề truy cứu nếu dự báo sai. Nhưng độc giả sẽ biết lựa chọn những nguồn có năng lực phân tích, dự báo tốt để đặt niềm tin. Dự báo trong nhiều trường hợp không nhất thiết phải xoay quanh một con số mà có thể là trao đổi về một hiện tượng thị trường hoặc xã hội sẽ xuất hiện trong những điều kiện nhất định trong tương lai. Ta bắt gặp nhiều chuyên gia chứng khoán phân tích thị trường, nhưng khi hỏi họ dự báo, câu trả lời nhận được thường bâng quơ và đi vòng. Chỉ những Merrill Lynch hay HSBC dám khẳng định đến một con số hoặc một diễn biến cụ thể. Không có khả năng phân tích hay dự báo, các tin bài sẽ chỉ còn mang tính đi theo, nói quanh cái cột trụ được ai đó cắm từ trước, giống như hiệu ứng bầy đàn.

Nói đến hiệu ứng bầy đàn, ai cũng biết, thậm chí có thể giải thích tương đối rành rọt một cách gần đúng. Các đơn vị truyền thông cũng sử dụng nhiều khái niệm này, vậy ai đưa ra đầu tiên để bây giờ nó được sử dụng như một loại “mốt"? Tháng 7/2000, TTCK Việt Nam mở cửa với hai hàng hoá đầu tiên: SAM và REE. Các khái niệm cổ phiếu, niêm yết, khớp lệnh, hay bù trừ, v.v.. còn rất xa lạ ngay cả với phần đông những nhà đầu tư tiên phong trên TTCK. Nhiệt huyết và niềm tin vào tương lai phát triển thị trường thì có thừa.

Nhưng có câu hỏi khiến nhiều người khác băn khoăn "Vì sao các nhà đầu tư trên thị trường chứng khoán có động thái gần như đồng nhất khi đồng loạt bán hoặc cùng lúc mua cổ phiếu?" Chừng nào chưa có câu trả lời, chưa thể lý giải tại sao chỉ trong vài ba tuần lễ giá cổ phiếu có thể giảm tới vài chục phần trăm mặc dù vận hành của công ty niêm yết không điều chỉnh đáng kể trong thời gian đó. Lục lại các kết quả nghiên cứu khoa học, trong lịch sử phát triển tài chính thế giới, một 
hiện tượng được miêu tả tương tự như vậy có tên gọi "herd mentality" (hay "herd behavior"). Thuật ngữ tiếng Anh được sử dụng ở đây, bởi tại thời điểm đầu năm 2001, chính tôi cũng lúng túng không biết nên sử dụng từ tiếng Việt nào cho hợp lý cả, dù đọc rất nhiều và đã tìm gặp, trao đổi với nhiều người trong lĩnh vực này. Mãi tới cuối năm đó, trong một bài báo trên Thời báo Kinh tế Sài Gòn thuật ngữ "hiệu ứng bầy đàn" mới lần đầu tiên được chúng tôi sử dụng (Lê Vương, 2001). Những điều chỉnh là cơ sở cho hệ thống khớp lệnh liên tục, từ đó nâng cao trách nhiệm của nhà đầu tư trong quyết định thực hiện đầu tư cũng được đề cập tới trong bài báo này.

Tới năm 2004, tôi và giáo sư André Farber sử dụng một số phương trình tuyến tính để kiểm định sự tồn tại hiệu ứng này với TTCK Việt Nam và kết luận tính rằng bầy đàn rất khó tắt, trừ khi có những thay đổi lớn về cấu trúc vi mô của TTCK. Ảnh hưởng mạnh nhất lên tính bầy đàn là tập hợp tin mà trong ngành tài chính thường gọi là một sigma-đại số. Việc không phân loại được và mất khả năng phân tích chính là nguyên nhân.

Như vậy mất ba năm đề từ một nghi vấn có thể trở thành một lập luận có căn cứ và đáng tin cậy. Trong khoảng thời gian đó, chưa có nghiên cứu thống kê nào chứng minh hay đưa ra các bằng chứng khoa học về sự tồn tại của hiệu ứng này trên TTCK VN. Nếu báo chí có sử dụng và nói về khái niệm này thì cách tiếp cận sẽ là nói về một nghi vấn, vấn đề là rất nhiều bài viết lại nhắc đến "một nghi vấn" như một sự quả quyết. Kết luận xin nhờ mọi người đưa ra.

Ở trên có nhắc đến vấn đề bối cảnh thông tin. Bối cảnh thông tin chứa đựng cả tính công bằng và phương pháp hợp lý. Đối với doanh nghiệp, việc truyền thông cái gì và truyền thông thế nào rất

Gần đây các vấn đề xung quanh câu chuyện FPT được báo chí nhắc nhiều. Nếu vẽ một bức tranh toàn cảnh, ta có thể thấy ngay lượng thông tin chính thống từ FPT ra ngoài không nhiều nếu không muốn nói là rất ít và với một số sự kiện thì thậm chí là không có phản hồi trực tiếp từ FPT. Báo chí phân tích, đưa tin rất nhiều xoay quanh những vụ việc cá nhân của thành viên hội đồng quản trị (HĐQT), việc sử dụng thương hiệu FPT hay việc HĐQT bán cổ phiếu. Không nói về tính đúng sai nhưng rõ ràng những gì được đăng tải trên các phương tiện truyền thông có tác động rất rõ rệt đến tâm lý công chúng đầu tư. Vai trò định hướng của các đơn vị truyền thông như thế rất quan trọng. FPT đang rất nỗ lực tái tạo các hiệu ứng truyền thông tích cực và chủ động. Đây là điều đáng học tập cho các doanh nghiệp niêm yết. quan trọng. Không phải doanh nghiệp nào cũng có bộ phận quan hệ công chúng - quan hệ nhà đầu tư đủ tốt để có tương tác đủ với giới truyền thông qua đó đảm bảo tính chính xác của thông tin và cân bằng được các sắc thái cảm xúc trong bối cảnh thông tin.

Ở đây, đã động chạm vào một vấn đề cực kỳ nhạy cảm của quản trị doanh nghiệp đó là Corporate Governance (CG) - tạm dịch là hệ thống quản trị và kiểm soát xung đột hay hệ thống "cơ chế" trong doanh nghiệp. CG ngày càng thu hút sự chú ý của đông đảo công chúng vì tầm quan trọng rõ rệt của chủ đề này đối với sức khỏe của doanh nghiệp và sự lành mạnh của xã hội nói chung.

Xin phép được lấy Hoa Kỳ làm ví dụ, đơn giản bởi đây là quốc gia có nhiều tập đoàn 
quy mô lớn nhất thế giới và tương ứng các hệ thống CG cũng sẽ phát triển nhất. Hệ thống CG ở Hoa Kỳ được triển khai trên ba nguyên tắc:

Thứ nhất, sử dụng các thành viên Hội đồng Quản trị (HĐQT) độc lập (independent directors) để kiềm chế quyền lực của ban giám đốc, đồng thời bảo vệ quyền lợi của các cổ đông.

Thứ hai, sử dụng và tín nhiệm giới kế toán để trình báo cáo tài chính có tính xác thực nhằm giúp cổ đông có thông tin đầy đủ khi đầu tư vào công ty.

Thứ ba, sử dụng và tín nhiệm các nhà phân tích tài chính để xem xét, phân tích các triển vọng kinh doanh và mức độ lành mạnh về tài chính của các công ty đang và sẽ phát hành chứng khoán ra công chúng nhằm cung cấp đầy đủ thông tin cho công chúng muốn đầu tư. Dịch vụ chuyên môn này rất cần thiết cho các nhà đầu tư cá nhân không đủ hiểu biết về tài chính, để đánh giá thông tin mà các công ty cổ phần bắt buộc phải công bố ra công chúng. Khi một công ty cổ phần hoạt động kém hơn mức trong ngành hay của thị trường, hoặc thiếu cơ chế quản trị thích đáng, các nhà đầu tư sẽ phản ứng bằng cách bán cổ phần của họ, là một hình thức áp đặt kỷ luật của thị trường lên ban giám đốc công ty. ${ }^{5}$

Nguyên tắc thứ hai và thứ ba dựa trên nguyên tắc công khai hóa thông tin. Chính công chúng đầu tư (chứ không phải những người có nhiệm vụ điều tiết, kiểm soát) có khả năng tốt nhất để tự quyết định lấy việc đầu tư của mình vì chỉ có họ mới biết rõ hoàn cảnh và mức độ sã̃n sàng chịu rủi ro của mình. Tuy nhiên, họ chỉ có thể có quyết định xác đáng khi có tất cả thông tin cần thiết. Triết lý kinh doanh dựa trên việc công khai hóa thông tin đòi hỏi các công ty đang và sẽ phát hành chứng khoán ra công chúng phải thực hiện việc công bố thông tin đầy đủ và xác thực cho các nhà đầu tư tương lai và các cổ đông hiện hữu. Việc này rõ ràng cần sự hỗ trợ rất lớn từ các đơn vị truyền thông tài chính uy tín - khách quan.

Tính chính xác, trung lập, kịp thời của thông tin - truyền thông được trình bày thành một học thuyết có thể coi là kinh điển, được gọi tên là lý thuyết thị trường hiệu quả (EMH). Một thị trường (chứng khoán) hiệu quả là nơi mà giá chứng khoán điều chỉnh nhanh chóng mỗi khi xuất hiện thông tin mới và do đó, mức giá hiện tại của một chứng khoán bất kỳ là kết quả phản ánh mọi thông tin liên quan đến nó. Những nghiên cứu nhằm phân tích mức độ hiệu quả của thị trường vốn đã được tiến hành trong suốt gần 30 năm qua. Hiệu quả của thị trường vốn cũng là một trong những vấn đề gây tranh cãi nhất trong các nghiên cứu đầu tư bởi các ý kiến đánh giá về hiệu quả này là rất khác nhau.

Hiệu ứng giá chứng khoán điều chỉnh nhanh chóng với ảnh hưởng từ các thông tin được gọi tên là "thị trường hiệu quả về mặt thông tin". Có ba cơ sở cho giả thuyết về thị trường hiệu quả.

\footnotetext{
${ }^{5}$ Một số vấn đề liên quan đến Corporate Governance có thể tham khảo thêm trong luận văn thạc sĩ Lê Nhị Năng, phó TGĐ Sàn Giao dịch Chứng khoán TP. HCM. Đây là luận văn tôi đã phản biện chính, trong đó có những nội dung được đánh giá tốt và đặt ra vấn đề đúng thời điểm, đúng cách thức.
} 
Giả thuyết tiền đề của EMH cho rằng cần có một số lượng lớn các đối thủ cạnh tranh tham gia thị trường với mục tiêu tối đa hoá lợi nhuận, họ tiến hành phân tích và định giá các loại chứng khoán một cách hoàn toàn độc lập với nhau.

Giả thuyết thứ hai là những thông tin mới về chứng khoán được công bố trên thị trường một cách ngẫu nhiên và tự động, và việc quyết định về thời điểm công bố thông tin cũng độc lập lẫn nhau.

Giả thuyết thứ ba, đặc biệt quan trọng, là các nhà đầu tư luôn tìm mọi cách điều chỉnh giá chứng khoán thật nhanh nhằm phản ánh chính xác ảnh hưởng của thông tin. Mặc dù sự điều chỉnh của giá có thể là không hoàn hảo, tuy nhiên nó không hề ưu tiên cho một yếu tố nào. Có khi sự điều chỉnh là quá mức, cũng có khi là dưới mức cần thiết, nhưng ta không thể dự đoán được điều gì sẽ xảy ra ở mỗi thời điểm xác định. Giá chứng khoán được điều chỉnh một cách nhanh chóng là bởi số lượng lớn các nhà đầu tư với mục tiêu tối đa hoá lợi nhuận cạnh tranh với nhau.

Hiệu quả kết hợp từ (i) thông tin thị trường là ngẫu nhiên và độc lập và (ii) một lượng lớn các nhà đầu tư cạnh tranh với nhau phân tích các thông tin mới và điều chỉnh giá cổ phiếu một cách nhanh chóng nhằm phản ánh các thông tin này, mang ý nghĩa mọi người đều hi vọng giá sẽ thay đổi một cách ngẫu nhiên và độc lập. Quá trình điều chỉnh này đòi hỏi một số lớn các nhà đầu tư hướng theo những chuyển dịch của chứng khoán, phân tích tác động của các thông tin mới đối với giá trị của nó và tiến hành mua vào hoặc bán ra cho tới khi giá chứng khoán được điều chỉnh sao cho phản ánh chính xác các thông tin.

Cuối cùng, bởi tất cả các thông tin sẽ điều chỉnh giá chứng khoán, do đó những mức giá này sẽ phản ánh tất cả các thông tin được công bố công khai tại bất kỳ thời điểm nào. Vì vậy, giá chứng khoán nào mà bất biến tại mọi thời điểm có thể là do kết quả phản ánh sai thông tin và cũng có thể mang lại rủi ro với người sở hữu nó. Vì lẽ này, trong một thị trường hiệu quả, thu nhập kỳ vọng ẩn trong mức giá hiện tại của chứng khoán cũng sẽ phản ánh rủi ro của nó.

Ta đi qua một loạt các khái niệm, học thuyết đến những nghiên cứu và bằng chứng thực tế cho thấy (i) vai trò của truyền thông tài chính với thị trường tài chính, với doanh nghiệp và điển hình với thị trường chứng khoán là rất rõ ràng; (ii) hệ thống truyền thống tài chính ở Việt Nam đang có ảnh hưởng thực sự tuy nhiên vẫn còn hạn chế về chất lượng thông tin và năng lực xử lý. Như thế nhu cầu định hướng, trao đổi và hợp tác thường xuyên giữa các hệ thống truyền thông là rất quan trọng để đảm bảo tính thống nhất, điều chỉnh cảm xúc và góp phần làm lành mạnh thị trường.

\section{Giả định-Giả thiết-Khuôn khổ-Chứng minh-Kết luận}

\section{Cần một hệ thống phương pháp}

Quá trình đi đến một kết luận, bất kể mức độ phức tạp thế nào đều sẽ trải qua một quy trình năm bước. Có thể trong một số tình huống cụ thể, các bước gần nhau được gộp lại, tuy nhiên khi cần đi vào chi tiết phân tích, việc định hình rõ các bước là cần thiết. Năm bước đó bao gồm 
1. Giả định: trước khi tiếp cận vấn đề, ta nhìn xuống dưới nền sự vật/sự kiện. Bất kể sự vật/sự kiện nào cũng có những giả định nền tảng bên dưới đảm bảo cho sự tồn tại và xuất hiện của sự vật, sự kiện đó. Chẳng hạn khi một doanh nghiệp muốn công bố thông tin về bán phát hành thêm cổ phiếu, báo Đầu tư chứng khoán thường nằm trong nhóm đầu tiên được nghĩ tới cho mục đích truyền thông ra công chúng. Để đi đến hiện tượng này, trên thực tế đã có sẵn trong "bộ nhớ" người lãnh đạo hoặc người trực tiếp chịu trách nhiệm lựa chọn, các giả định cho phép tên báo ĐTCK hiện ra trước tiên sẽ là: đây là báo chứng khoán, nói chuyện chứng khoán, báo của một cơ quan nhà nước, báo được giới đầu tư đọc nhiều,... và nhiều giả định cơ sở khác mà tổng hợp nó lại cho phép hiện tượng xuất hiện ý nghĩ lựa chọn báo ĐTCK. Tất nhiên để đi đến quyết định thực sẽ còn cần nhiều yếu tố khác.

2. Giả thiết: trên cơ sở đã nắm vững những giả định nền tảng, người ta sẽ xây dựng các giả thiết, coi đó như những công cụ căn bản để tiến đến kết luận cần thiết. Chẳng hạn để tìm kiếm một phương án đạt tới mức vốn hóa thị trường bằng 50\% GDP trong vòng 2 năm tới thì trước khi đề xuất các giải pháp kích thích cổ phần hóa, hỗ trợ doanh nghiệp ta vẫn cần giả thiết rằng GDP tiếp tục tăng trưởng đều đặn $10 \%$ như hiện tại trong 2 năm tới.

3. Khuôn khổ: khuôn khổ là một hệ bao gồm các giả định nền và các giả thiết tạo khung, trên cơ sở các nền và khung đó, người ta nghiên cứu, lựa chọn, xây dựng phương pháp tiếp cận, xử lý thích hợp. Khuôn khổ này chính là căn cứ lập luận cho bất kỳ tư duy và hành động nào tiếp theo trọng phạm vi công việc này hay nói cách khác là căn cứ lô-gích khoa học.

4. Chứng minh: với khuôn khổ được xác lập, phương pháp lựa chọn, việc nỗ lực tìm kiếm các thông số, dữ kiện để chứng minh theo mục tiêu đề ra sẽ có định hướng rõ ràng, có thể khó nhưng chắc chắn đến đích. Như thế nếu ngay từ lúc lập giả thiết, xây dựng khuôn khổ đã không đúng định hướng thì khả năng đến bước này việc chứng minh sẽ vĩnh viễn không đạt mục tiêu hoặc nếu có đạt thì là may vô cùng lớn.

5. Kết luận: kết luận là thành quả cuối cùng của quá trình này. Nhưng kết luận không có nghĩa là hết, kết luận đưa câu chuyện/vấn đề đang giải quyết đến một ngưỡng mới thậm chí đến một vấn đề phải giải quyết khác.

Đây là năm bước trong một quá trình nghiên cứu. Nghiên cứu có vai trò quan trọng trong khoa học tự nhiên, xã hội và kinh tế-kinh doanh. Điều này có lẽ ít người phản đối. Trước hết ta cần một lý giải vì sao lại chọn hệ thống phương pháp nghiên cứu khoa học để nói chuyện làm truyền thông.

Thứ nhất, kiến thức của loài người về tự nhiên và xã hội được làm giàu và trở nên sâu sắc hơn rất nhiều, nếu không nói là chủ yếu, nhờ hệ thống nghiên cứu khoa học. Hệ thống phương pháp nghiên cứu khoa học tạo ra hiểu biết mới, ở mức ngày càng cao hơn, phục vụ sự phát triển của xã hội.

Thứ hai, bản thân mỗi bài tổng hợp, phân tích, bình luận, dự báo cũng là những nghiên cứu ở các cấp độ và quy mô khác nhau, được xếp chung vào nhóm nghiên cứu kinh doanh. Những nghiên 
cứu này sát với cuộc sống kinh doanh và có thể có ứng dụng nhanh chóng vào thực tiễn. Không giống như các sản phẩm khoa học tự nhiên hay kỹ thuật, khoảng cách từ phòng thí nghiệm tới thực tiễn cuộc sống cần nhiều năm, còn các sản phẩm và kiến thức từ nghiên cứu kinh doanh có tính ứng dụng rất cao.

Ở cấp độ cao, những công trình nghiên cứu kinh doanh mang lại lợi ích rất lớn cho xã hội. Chẳng hạn công trình nghiên cứu đầy tính trừu tượng của Harry Markowitz về lý thuyết toán học cho lựa chọn danh mục tài sản đầu tư (vẫn gọi là phương pháp trung bình-phương sai) đã nhanh chóng trở thành các ứng dụng trên máy tính khắp thế giới chỉ sau vài năm. Nó góp phần dỡ bỏ các hàng rào ngăn cản nhiều quỹ đầu tư vượt ra khỏi biên giới của thị trường truyền thống, để đồng vốn chảy tới các thị trường nhiều rủi ro hơn.

Lý thuyết CAPM (mô hình định giá tài sản vốn) của William Sharpe, Jan Mossin và John Lintner, rất quen thuộc trên TTCK toàn cầu, được ứng dụng rất rộng rãi kể từ những năm chúng ra đời 1963-1965. Tới những năm 1970-1990 lý thuyết này đã quen thuộc với rất rất nhiều người làm nghề kinh doanh tài chính và đầu tư vốn, mặc dù vẫn còn những nhược điểm. Đó cũng là niềm cảm hứng để rất nhiều quỹ đầu tư theo chỉ số thị trường ra đời, ngày nay có thể tính bằng hàng chục ngàn.

Lý thuyết option của Fisher Black, Myron Scholes và Robert Merton ra đời năm 1972 thì năm 1973 khai trương sàn giao dịch option lừng danh, cũng là lớn nhất thế giới, CBOT ở Chicago. Khi khai trương nó, người ta cũng không quên nhắc tới đóng góp của công thức Black-Scholes đã được nhanh chóng cài vào rất nhiều máy tính của dân chuyên làm tài chính của các hãng như Texas Instruments hay HP.

Mặc dù còn vô số ví dụ khác nói lên hệ thống phương pháp nghiên cứu khoa học kinh doanh luôn gần gũi với cuộc sống thực tế. Đáng lưu ý hơn, những nghiên cứu kinh điển trên bắt nguồn từ những bài báo, nơi ý tưởng được phôi thai. Nói cho chính xác, các đầu bài của khoa học nằm trong cuộc sống thật đang diễn ra sôi động từng ngày và làm báo, làm truyền thông, ở góc độ nào đó, cũng có thể coi là làm khoa học. Vì thế, cần đảm bảo tính khoa học cho báo chí và truyền thông.

Trong quá trình làm việc, những công việc đã quen thuộc hàng ngày, nhắm mắt cũng nhớ đến từng chi tiết cho phép ta triển khai rất nhanh mà không phải quan tâm đến những vấn đề thuộc về phương pháp và tư duy. Ở đó trực giác của người làm việc cho phép họ quyết và làm theo thói quen, theo cảm xúc. Tuy nhiên, luôn có những thời điểm mà thông tin hiện có không đủ để cân nhắc một quyết định. Đó có thể chỉ bởi quyết định quá quan trọng, vấn đề quá phức tạp, nguyên nhân của sự cố chưa thể xác định, hay trực giác không đáng tin cậy. Lúc này, một phương pháp tiếp cận và giải quyết khoa học sẽ phát huy tác dụng giảm thiểu khả năng đưa ra quyết định sai lầm. Điểm yếu của chúng ta hiện nay là một hệ thống phương pháp làm việc lô-gích, hiệu quả, có định hướng rõ ràng cho phép ta yên tâm, kiên trì theo đuổi cho đến mục tiêu cuối cùng.

Cũng không cần đợi tới lúc triển khai thực hành, điểm yếu đó đó bộc lộ khá rõ trong các kết quả nghiên cứu trong thời gian học tập ở các bậc đại học và thậm chí, cả cao học và nghiên cứu sinh. 
Thời gian làm công tác nghiên cứu tại Bỉ, tôi có đọc nhiều luận văn tốt nghiệp thạc sĩ và tiến sĩ. Điểm chung dễ nhận thấy là phần khảo sát, so sánh giữa các cách thức giải quyết mục tiêu nghiên cứu, các kết quả đã đạt được trước đó luôn trình bày rất công phu và làm kỹ. Bậc nghiên cứu càng cao, nội dung tinh chỉnh và phát triển tiếp các nguyên lý, mô hình đã được ứng dụng càng được chú trọng. Điều này khá tương phản với các luận văn tại Việt Nam. Phần lớn nội dung trình bày phương pháp luận chỉ dừng ở mức chép, hay dịch lại, hay cóp nhặt rời rạc từ nhiều nguồn. Sự liên kết, chọn lọc và kế thừa kết quả nghiên cứu sẵn có rất yếu. Chỉnh sửa và mở rộng phương pháp hầu như không có. Chúng ta yếu phương pháp có lẽ bởi ngay từ ban đầu chúng ta đã không coi trọng phương pháp.

Việc kết hợp khéo léo, nhuẫn nhuyễn óc phân tích cùng phương pháp làm báo khoa học cho phép người phóng viên một mặt có góc tiếp cận tốt, mặt khác có cách triển khai hợp lý, đi đến rốt ráo và bản chất vấn để - vốn là những yêu cầu quan trọng trong thông tin truyền thông tài chính. Như thế, để đạt đến tính chuyên nghiệp, đối với người làm truyền thông phải là một hành trình dài với nhiều trải nghiệm và cảm xúc.

\section{Truyền thông chuẩn tắc và truyền thông thực chứng}

Khái niệm trên được vay mượn từ kinh tế học. Theo cách tiếp cận, kinh tế học ngày nay được chia thành kinh tế học chuẩn tắc và kinh tế học thực chứng.

Kinh tế học chuẩn tắc tiếp cận hướng đến những mệnh đề được nêu lên và thông qua lập luận lôgích người ta cho rằng những lập luận này đúng, nên đi theo.

Kinh tế học thực chứng tiếp cận dựa trên một vài mệnh đề có sẵn (có thể là mệnh đề chuẩn tắc ở trên), từ đó căn cứ vào thực tiễn, thông qua phân tích khách quan để đưa ra các bằng chứng cho việc ra quyết định có nên theo hay không.

Sở dĩ nhắc đến hai khái niệm này là vì trong truyền thông, ta bắt gặp một sự phân loại tương tự. Có nghĩa là, có truyền thông chuẩn tắc và truyền thông thực chứng. Truyền thông chuẩn tắc là dạng thức truyền thông mang tính định hướng, thông tin về các chủ trương, đường lối, các chính sách,... mà đối tượng đọc sẽ cần ghi nhận và tuân thủ. Những báo như Nhân Dân, Đài Truyền hình Việt Nam, các văn kiện,... là những hình thức truyền thông chuẩn tắc.

Truyền thông thực chứng lại căn cứ trên những nguyên lý chuẩn tắc và sử dụng các kĩ thuật phân tích, so sánh, các lập luận, số liệu để mổ xẻ vấn đề, từ đó rút ra các kết luận về việc nên hay không, đúng hay sai,...

Trong các thông tin, bài viết, dù hướng đến khai thác một sự vật, hiện tượng nào thì người phóng viên luôn cần lưu ý những mệnh đề chuẩn tắc nền tảng. Nói cách khác, phóng viên muốn sản xuất ra bài viết tốt sẽ cần cân bằng hai yếu tố thực chứng và chuẩn tắc trong quá trình truyền tải nội dung. Việc lựa chọn đứng nghiêng về bên nào sẽ quyết định tác động của tin - bài đến đám đông. Cách duy nhất để đảm bảo tính hợp lý và cân bằng là rèn luyện óc phân tích và xây dựng hệ thống phương pháp khoa học.

Phương pháp phân tích và kỹ thuật chứng minh 
Phương pháp tư duy phân tích đặc biệt có ý nghĩa trong tác nghiệp báo chí - truyền thông. Với cùng một sự việc, cách nhìn nhận, đánh giá truyền thống - cách mà ai cũng có thể làm - sẽ không mang lại sự khác biệt vốn đã khan hiếm trong ngành công nghiệp khao khát sáng tạo. Lời giải cho tính sáng tạo chính là óc tư duy phân tích. Không dừng ở óc tư duy, mà xa hơn, ta có cách tiếp cận vấn đề hoàn toàn mới, phân tích ở góc độ khác và đưa ra những lập luận, đánh giá sáng tạo.

Cách tiếp cận lật lại vấn đề như thế được gọi tên riêng là Devil's Advocate. Đây là kĩ thuật lật ngược dần từng nhóm giả định để tìm hiểu gốc rễ và tư duy theo hướng khác. Khi lật ngược lại vấn đề tưởng chừng nhưng đã xong hoặc không thể giải quyết, ta đồng thời xem xét lại toàn bộ, phân tích từng giả định ngầm bên dưới để dẫn đến hiện trạng. Thông thường người áp dụng kĩ thuật này sẽ tìm ra được một giả định ngầm do bản thân tự xác lập, do nằm chìm bên dưới và ở dạng giả định, nó ngăn cản một số yếu tố khác có thể được sử dụng để giải quyết tận gốc vấn đề.

Trong truyền thông, việc đặt được câu hỏi đúng cũng quan trọng như phân tích tốt tình huống. Đặt câu hỏi sai đồng nghĩa với các nỗ lực theo sau đều vô nghĩa. Sử dụng kỹ thuật đặt câu hỏi ngược cho phép xác định đúng vấn đề cốt lõi để đưa ra câu hỏi bao trùm.

Xét thử một ví dụ: khi thị trường đột ngột xuất hiện hiện tương mua bán cổ phiếu tần suất cao, khối lượng giao dịch tăng vọt và kéo dài trong một khoảng thời gian đủ dài. Việc đầu tiên sẽ là các tin bài, ý kiến, bình luận thị trường nóng, màu xanh che phủ, khởi sắc,... Đâu đó tiến xa hơn đi tìm hiểu nguyên nhân và kết luận đám đông trên thị trường đang bị cuốn theo việc này. Tư duy này nhanh chóng dẫn tiếp đến một kết luận - hiệu ứng bầy đàn.

Có một số câu hỏi rất căn bản có thể đặt ra:

- Một hiện tượng mua bán có thể suy rộng cho đám đông?

- Nếu là đám đông, đó có phải là bầy đàn?

- Nếu là bầy đàn thì dẫn đến cái gì?

Đến đây thì câu trả lời ngắn gọn như sau: hiện tượng mua bán không nhất thiết là đám đông. Một vài tổ chức với quy mô tài chính lớn cùng giao dịch cũng có thể tạo ra hiện tượng, nhưng rõ ràng họ không thể tạo thành đám đông.

Nếu là đám đông thật, cũng chưa chắc là phải bầy đàn. Để hình thành bầy đàn, điều kiện cần là đám đông, điều kiện đủ là đám đông đó có chung tâm lý, cảm xúc hay chính xác hơn là có kỳ vọng đồng nhất về thị trường. Từ hai yếu tốt này mới cấu thành hiện tượng đồng loạt mua, đồng loạt bán được gọi với cái tên hiệu ứng bầy đàn.

Nếu là bầy đàn, sẽ có một số hiệu ứng tiêu cực. Trước hết là một sự khủng hoảng thanh khoản, sẽ chẳng có một TTCK nào đáp ứng nổi nếu tất cả cùng mua hoặc tất cả cùng bán. Còn nhớ hệ thống giao dịch của NYSE cũng chào thua trong đợt bán tháo rất lớn trên thị trường Mỹ hồi cuối tháng 2 năm nay. Một hiệu ứng tiêu cực khác là tình trạng trục lợi qua giao dịch mà không hề chịu rủi ro. Xa hơn khi đã kết thúc rồi, vẫn còn những hiệu ứng tiêu cực đọng lại về tâm lý, cảm xúc và niềm tin. 


\section{Truyền thông tài chính: Từ cảm xúc tới quyết định}

Khi thị trường tài chính và nhất là thị trường chứng khoán (TTCK), đã phát triển toàn cầu, người ta lập tức đã để ý tới tác động của các dòng thông tin lên cảm xúc con người. Các dòng thông tin tốt, xấu, vừa phải... mô tả nhiều khía cạnh khác nhau về tình hình hoạt động kinh tế, các xu hướng quan trọng như trong mô hình PEST, các trạng thái cảm xúc của số đông nhà đầu tư và những người liên quan, v.v.. đã góp phần dịch chuyển kỳ vọng không đồng nhất trong từng nhóm các nhà đầu tư. Dĩ nhiên, tìm sự đồng nhất là không thể, ngay trong một nhóm có sự đồng nhất tương đối cao (Homogeneity). Tuy vậy, dòng thông tin tác động mạnh có thể khiến người ta điều chỉnh kỳ vọng của mình, khi chúng khá sát nhau (khoảng cách trở nên rất nhỏ), hiệu ứng bầy đàn xảy ra. Hiệu ứng bầy đàn xảy ra mạnh và lâu dài sẽ dẫn tới thị trường mất cân bằng trong khoảng thời gian lâu dài... Điều này dễ dẫn tới các nhà đầu tư cũng điều chỉnh hành vi sao cho có lợi nhất. Xu hướng tiếp tục này chính là một phần nội dung của hiệu ứng GARCH mà chúng ta có thể bắt gặp rất nhiều trong các nghiên cứu khoa học thực nghiệm về kinh tế-tài chính, trên các đối tượng là cổ phiếu, vàng, đá quý và ngoại hối (Hoàng, 2004).

TTCKVN không thể tránh khỏi quy luật này. Ban đầu, chúng ta nhận thấy vào những năm 20002002, các tập thông tin phi chính sách không ảnh hưởng bao nhiêu tới TTCKVN và hành vi đầu tư. Vào thời điểm đó, các dòng thông tin chính sách có tác động mạnh nhất theo nghiên cứu của chúng tôi (Vương, Farber, 2004). Ở đây, chúng ta hiểu rằng thông tin chính sách bao gồm cả những điều chỉnh kỹ thuật và cấu trúc vi mô, tương đối mang tính chất bắt buộc, tác động trực tiếp lên quyết định giao dịch của nhà đầu tư.

Nhưng sang thời kỳ 2005-2007, khi UBCKNN và Sở Giao dịch đã tương đối thống nhất các quy tắc, thể chế và phạm vi tác động kỹ thuật qua chính sách, thì vai trò của truyền thông tài chính quay trở về đúng với bản chất phổ quát của nó. Chúng ta lại bắt gặp việc giao dịch trong tập thông tin mờ, quyết định cảm xúc, thông tin pha trộn chưa lọc hay có lọc theo cách riêng, báo chí và hệ thống truyền thông ít kiểm soát (các forum, websites không kiểm định, tin đồn và rỉ tai...) Khi hệ thống truyền thông chính thức còn hạn chế về khối lượng và chất lượng thì các hệ thống "thay thếbổ trợ" hoạt động rất mạnh, kiến tạo các kỳ vọng đầu tư và cách nhìn về rủi ro rất khác nhau.

Nhiều doanh nghiệp đã có thể thu hút rất nhiều vốn đầu tư từ tiền của do xã hội đem lại. Bằng một số "kỹ thuật bắn tin-rỉ tai-đồn đại" người ta cũng có thể kích thích nhu cầu đầu tư cao độ và việc quyết định được đưa ra trong trạng thái thiếu thông tin. Việc quản trị doanh nghiệp nghiêm túc xét thực tế này như một sự xung đột tiềm tàng và rủi ro cho cổ đông nhỏ, những người thường là không có điều kiện giao tiếp và tiềm lực quan hệ để có những thông tin tốt nhất. Doanh nghiệp càng lớn, thương hiệu càng lớn thì tính "dễ tổn thương" của cổ đông nhỏ càng cao. Đợt sụt giảm giữa năm 2007 cũng khiến cho nhiều người đầu tư các cổ phiếu tự do (vẫn gọi là OTC) vất vả xử lý số cổ phiếu chưa bán được trong lúc thông tin nhiễu loạn và giá cả không thể lường trước.

Ma trận $\Omega(4$ x 4): Cảm xúc 
Câu hỏi nghiên cứu được đặt ra là các quyết định đầu tư, mở rộng ra là kinh doanh, chịu tác động của những yếu tố nào? Cả một công nghệ đầu tư-kinh doanh hiển nhiên chẳng thể dễ. Khó hơn cả là trong rất nhiều tình huống, chúng ta phải tạo ra công nghệ riêng, chứa cái "đặc sắc" của mình.

Lựa chọn một quyết định đầu tư cũng khó như vậy. Các thông số tài chính và phân tích kỹ thuật đưa ra nhiều gợi ý về mức giá hợp lý dành cho cổ phiếu mà chúng ta quan tâm. Thế nhưng, sự háo hức của các nhà đầu tư xung quanh dấy lên mối lo ngại rằng nếu không đặt mua với mức giá "cạnh tranh," chúng ta sẽ bỏ lỡ cơ hội sở hữu loại cổ phiếu hấp dẫn này. Cùng lúc, giá mua cao ẩn chứa rủi ro thua lỗ nhiều trong tương lai khiến chúng ta chần chừ.

Vì sao khó? Tôi tin là cảm xúc. EQ là thước đo mà người ta ngày càng nhận ra là quá quan trọng trong việc hình thành trí thông minh, thành công và các quyết định kinh doanh của loài người. Cảm xúc hơn thế nữa vô cùng khó đo đạc, bởi lẽ nó bị ngự trị bởi cái ma trận vuông $\Omega$ cấp $(4 \times 4)$ gồm các véc-tơ Hỷ-Nộ-Ái-Ó. Cái này xuất xứ phương Đông chính cống, nhưng ứng dụng mang màu sắc phương Tây. Kết hợp Đông-Tây nhuần nhuyễn sẽ cho ra những sản phẩm bất ngờ! Ta gọi sự bất ngờ, có tính mới và hữu ích bằng cái thuật ngữ sang trọng: "Sáng Tạo."

$\Omega(4 \times 4)$

Cắt lát sự phức tạp và những tính chất của

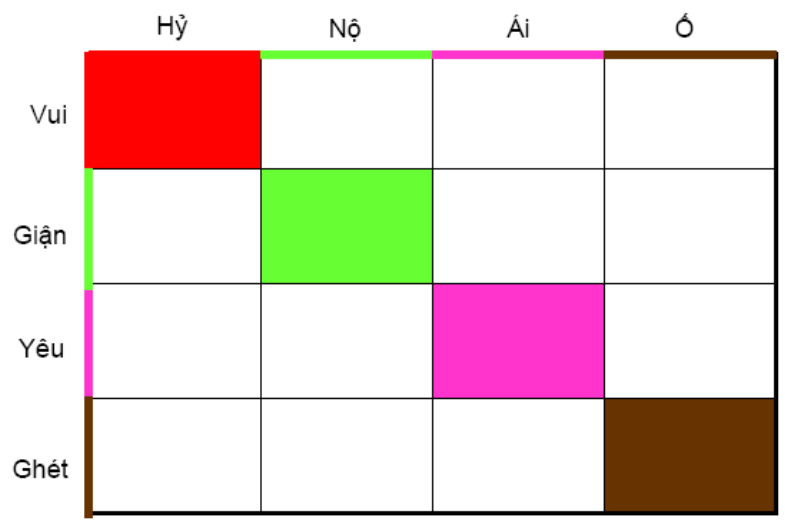
cái $\Omega(4 \times 4)$ này là cả một khối lượng công việc đồ sộ. Mỗi một bằng chứng của cá nhân các bạn nếu đã trải qua cũng có thể giúp làm sáng rõ hơn nó. Đây là nói chuyện thực tiễn, chứ lý thuyết thì cả ngàn trang.

Vậy thì $\Omega(4 \times 4)$ có phải là tất cả?

Cảm xúc là cái khó nắm bắt. Nhiều khi bạn giận dữ vô cùng và chỉ 1 giờ sau, nhận ra rằng, mình vừa rồi giận dữ rất vô lối. Nhưng khi đó, nó đã xảy ra rồi.

Khi nó xảy ra trong truyền thông kinh doanh, thật khó cứu vãn. Chúng ta hầu như không có dịp gặp lại đối tác hay cơ Trực giác và Lỷ tri tạo góc $180^{\circ}$ hội đầu tư lần thứ hai.

Thế thì, sa vào chủ nghĩa tự nhiên và để cái $\Omega(4 \times 4)$ này tuyệt đối chỉ đạo mình cũng chẳng phải tốt. Tôi mượn cái của ông Giáo sư khá nổi tiếng Bob Schlesinger nói khi trước. Quyết định khôn ngoan nó cần 2 véc-tơ vật lý: Lý trí

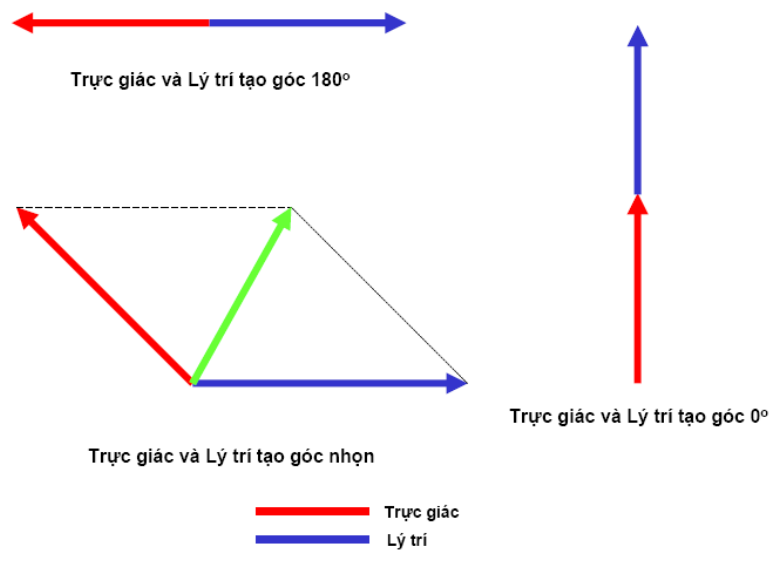
và Trực giác. Lý trí do các phương pháp, óc phân tích, lô-gích và thông tin tạo thành. Trực giác phần nhiều do cảm xúc. 
Hãy tưởng tượng rằng 2 véc-tơ này cùng xuất phát từ một gốc tọa độ, nhưng mũi tên ngược nhau (tức là nằm trên đường thẳng nhưng góc 180 độ) thì nó triệt tiêu nhau nhiều nhất có thể. Nếu góc bé lại, thì quy tắc vật lý nói rằng lực tổng hợp theo đường chéo hình bình hành. Khi 2 véc-tơ trùng khít lên nhau, góc 0 , thì độ lớn véc-tơ tổng hợp là lớn nhất.

Khoa học quản trị là tìm kiếm véc-tơ có độ lớn tuyệt đối lớn nhất với hi vọng rằng nếu hướng đó là đúng, chúng ta sẽ tới đích làm giàu nhanh nhất (tác động một lực lên một vật thể nằm yên sẽ tạo ra gia tốc. Gia tốc hình thành vận tốc. Và kết quả là có một chuyển động. Sản xuất ra thông tin cũng sẽ chạm phải vấn đề này.

\section{Vai trò giáo dục và định hướng thông tin của báo chí trên TTCK}

TTCK có cảm xúc hàng trăm năm và là quá trình có trí nhớ dài

Theo nhà sử học nổi tiếng người Pháp Fernand Braudel, ngay từ thế kỉ 11, ở Cairo, những thương nhân người Hồi giáo và Do Thái đã xây dựng nên những hiệp hội thương nghiệp đầu tiên và có những hiểu biết về các phương thức tín dụng và thanh toán, là mầm mống cho thị trường chứng khoán sau này (Saga-Thuật ngữ tài chính).

Từ giữa thế kỉ 13, các ngân hàng ở Venetia bắt đầu tiến hành những giao dịch đối với các chứng khoán do Chính phủ phát hành. Năm 1351, chính quyền Venetia đã ra lệnh nghiêm cấm việc phổ biến những tin đồn có mục đích là giảm giá trị các quỹ do Chính quyền sở hữu. Những ngân hàng ở Pisa, Verona, Genoa và Florence thuộc Italy đã bắt đầu tiến hành mua bán chứng khoán do Chính phủ phát hành từ thế kỷ 14 , điều này thực hiện được là vì đây là những thành bang độc lập, không nằm dưới quyền cai trị của một công tước nào, mà được điều hành bởi một hội đồng những người có ảnh hưởng và uy tín trong cộng đồng.

Sau đó, chính người Hà Lan khởi xướng mô hình công ty cổ phần, mà cổ đông có thể đầu tư vào để chia sẻ lợi nhuận cũng như thua lỗ. Năm 1602, Công ty Đông Ấn đã phát hành những cổ phiếu đầu tiên ra Sàn giao dịch chứng khoán Amsterdam. Đây là công ty đầu tiên trên thế giới phát hành cổ phiếu và trái phiếu. Sàn giao dịch chứng khoán Amsterdam cũng được coi là sàn giao dịch đầu tiên trên thế giới hoạt động một cách liên tục. Cũng người Hà Lan nghĩ ra các nghiệp vụ giao dịch chứng khoán như "bán khống", "giao dịch quyền chọn", "nghiệp vụ hoán đổi nợ-cổ phần", "nghiệp vụ ngân hàng thương mại" và nhiều công cụ đầu cơ khác mà cho đến ngày nay người ta vẫn còn sử dụng.

Ngày nay, thị trường chứng khoán thực sự trở thành cấu phần không thể thiếu trong các nền kinh tế hướng tới phát triển vững mạnh. Cũng giống như các thị trường khác trong nền kinh tế, TTCK vận động theo qui luật riêng. Quan sát lịch sử phát triển TTCK thế giới phản ánh "trí nhớ dài" của thị trường này qua các hiện tượng lặp lại. Một ví dụ tiêu biểu là hiện tượng "bong bóng chứng khoán."

Bong bóng trong lý thuyết kinh tế có thể hiểu theo ba định nghĩa tương đồng nhau: (i) Một chu kỳ kinh tế đặc trưng bởi quá trình mở rộng nhanh chóng sau một giai đoạn thị trường thu nhỏ trầm lắng; (ii) Hiện tượng giá tài sản tăng bùng phát, thường vượt ra ngoài giới hạn đảm bảo của các hệ số tài chính cơ bản và xuất hiện ở một số ngành nhất định, tiếp sau hiện tượng này là sự sụt giá 
rất nhanh và mạnh cùng làn sóng ồ ạt bán ra; và (iii) Là một học thuyết mô tả hiện tượng giá chứng khoán vượt quá giá trị chính xác của chúng và cứ tiếp tục tăng như vậy cho đến khi giá đột ngột rơi tự do và quả bong bóng vỡ.

"Bong bóng", xét trên khía cạnh tâm lý đầu tư, là một hiện tượng thể hiện một điểm yếu nhạy cảm trong cảm xúc của con người. Hiện tượng bong bóng hình thành khi nhu cầu của nhà đầu tư với một loại cổ phiếu lên quá cao, từ đó làm cho giá giao dịch vượt xa mọi mức được coi là chính xác và hợp lý tính toán dựa vào kết quả vận hành thực của doanh nghiệp phát hành. Giống như một bong bóng xà phòng mà trẻ con thường thích thổi, bong bóng đầu tư hình thành và tạo cho người ta cảm giác nó sẽ tồn tại mãi mãi. Nhưng bản chất những bong bóng xà phòng không được cấu tạo từ một vật liệu có thực, vỡ là kết quả tất yếu. Khi sự "vỡ" xảy ra, tiền đầu tư theo ảo giác bong bóng đó cũng sẽ bay theo gió (Phương, 2007).

Mặc dù đã được đúc kết thành lý thuyết và trở thành đối tượng nghiên cứu hấp dẫn nhiều nhà nghiên cứu, các cuộc khủng hoảng bóng bóng vẫn xuất hiện lặp đi lặp lại, theo trình tự thời gian có thể kể tới:

- Khủng hoảng hoa Tu-líp, Hà Lan: 1634-1637

- Bong bóng biển Nam, Anh: 1711-1720

- Bong bóng bất động sản Florida và đại khủng hoảng, Mỹ: 1929

- S Sụp đổ thị trường chứng khoán Mỹ: 1987

- Khủng hoảng châu Á: 1997

Quả là một sự ám ảnh dai dẳng với các nhà đầu tư trên thị trường tài chính.

TTCK VN nén 300 năm này vào 8 năm, và giải quyết bằng việc áp xuống các luật với các qui chuẩn hành vi trên thị trường

Trong khoảng 8 tháng gần đây, trên thị trường tài chính Việt Nam, người ta bắt đầu nhắc nhiều tới "quan hệ nhà đầu tư." Mỗi khi nói tới mối quan hệ, vấn đề thường đề cập là việc công bố thông tin doanh nghiệp. Hiển nhiên, điều đó rất đúng, vì doanh nghiệp chính là nờ "sản xuất" ra những thông tin tài chính, đầu tư, vận hành cho thị trường đánh giá và cân nhắc quyết định đầu tư.

Vậy rõ ràng quan hệ với công chúng đầu tư là một phần quan trọng của công tác $\mathrm{PR}$ doanh nghiệp. Xưa nay, công tác PR tập trung vào xây dựng thương hiệu hình ảnh doanh nghiệp, dẫn tới cảm xúc ủng hộ thương hiệu, với hi vọng rằng trong dài hạn, các sản phẩm sẽ có chỗ đứng và sự hiện diện tốt trên thị trường. Nói như Kotler thì đó là một bước để giành lấy trái tim người tiêu dùng và/hoặc khách hàng. Tôi có biết anh Andy Ho từ lúc còn ở Prudential, nay đã chuyển qua VinaCapital, trong một câu chuyện café sáng, nói ý cũng thú vị: Nếu là doanh nghiệp đang làm ăn tốt hiện nay, sẽ dồn rất nhiều tiền của để chỉ tập trung tạo dựng thương hiệu. Thương hiệu sẽ tác động rõ rệt lên cảm xúc thị trường. 
Nhưng bây giờ $\mathrm{PR}$ còn thêm nhiệm vụ chúng ta vừa nói và coi công chúng đầu tư vào cổ phiếu là một tập con quan trọng của đối tượng cần thực hành quan hệ hiệu quả. Trong giai đoạn của đầu tư và tiếp tục tìm kiếm nguồn lực cho đầu tư lâu dài, doanh nghiệp sẽ càng thấy việc quan hệ với cổ đông là nội dung PR có tỉ trọng tăng lên nhanh chóng. Một doanh nghiệp thành công sẽ có nhiều dự án, và có nhiều lần phát hành cổ phiếu sau IPO, gọi là SPO. Nếu doanh nghiệp muốn có lịch sử đại chúng lâu dài, trở thành cao niên, việc có hàng vài chục tới cả trăm vụ SPOs sẽ là hết sức quen thuộc. Không có chuyện một lần cho mãi mãi.

Việc chăm sóc thông tin và xây dựng cảm xúc tốt đẹp trong số các nhà đầu tư quả thật đã được chú ý, đặc biệt với các doanh nghiệp lớn có hệ thống quản trị hướng tới "thực hành tốt nhất" và muốn đi đường dài. Đó cũng là điều phân biệt với các doanh nghiệp có phép tính ngắn hạn. Vậy phía bên kia câu chuyện là: Nếu doanh nghiệp chưa đủ điều kiện và năng lực phục vụ truyền thông tài chính, quan hệ $\mathrm{PR}$ công chúng đầu tư thì sao? Rõ ràng là chưa nên bước lên vị trí đại chúng làm gì cả, vì đó sẽ là con dao hai lưỡi. Sức ép quan hệ về sau sẽ khiến Ban giám đốc mệt mỏi trong sự bị động của những thứ không thể không làm, trong khi có thể chưa biết làm thế nào. Làm bài tập ở nhà có vất vả thế nào thì cũng còn dễ chịu hơn ngồi ở phòng thi mà chưa biết cách làm bài.

Nội dung truyền thông tài chính, trong bối cảnh nhiệm vụ quan hệ công chúng đầu tư vừa nói, rất rộng. Nó cần một điểm chốt, cũng như các nguyên lý, để có thể ứng dụng thành công. Hiện tại, báo chí hay nhắc tới việc lập Phòng Quan hệ Nhà đầu tư (IR) cũng như việc "giao lưu" -- một từ trở thành mốt những năm gần đây do sự bùng nổ các gameshows và chương trình giao lưu.

Nhưng đó là cái vỏ. Nguyên lý quan trọng nhất để tìm đến sự cốt lõi trong hiệu quả truyền thông $I R$ là: (i) Thông tin trọng yếu; (ii) Tình tiết trung thực; (iii) Diễn giải khách quan; (iv) Tính hợp lý cực đại của Không-Thời gian (trong quan hệ với các phương tiện có thể sử dụng); và (v) Sự cân bằng trước các đối tượng đầu tư: Đã-Đang và Sẽ (Hoàng, 2007).

Đứng về mặt "phương tiện truyền thông" chúng tôi muốn lưu ý một điểm là không chỉ nói tới máy móc, hình thức bản tin hay cách thức tải tin, mà còn nói tới cả chủ thể nào đứng ra truyền tin. Các bạn thấy đó, vẫn một báo cáo nhưng người Việt Nam phát ngôn thì phản ứng xã hội khác xa so với HSBC hay là Merrill Lynch. Xét quan hệ giữa giới đầu tư quốc tế và TTCKVN thì lúc này HSBC hay M.L. có thể xem như đóng một vai trò phương tiện truyền thông thượng hạng.

Chúng tôi biết tới một trường hợp một công ty lớn ở miền Nam, trước khi đại chúng hóa "một cách âm thầm" có vận hành kinh doanh và hiệu suất sử dụng vốn lớn, đó là kết quả tích cực của tinh thần khởi nghiệp. Ngay khi nguồn lợi tạo ra từ TTCK của các nhà đầu tư cá nhân được nhìn thấy rõ, chủ doanh nghiệp đã tích cực $\mathrm{PR}$ bằng "thông tin không chính thức" và gây ra một làn sóng mua cổ phiếu công ty với giá cao, lúc đỉnh điểm tới gần 7 lần mệnh giá. Nguồn lợi này nhanh chóng được đưa vào "nghị sự chính yếu" và các công ty con được lần lượt ra đời với mức giá giao dịch xung quanh 3-4 lần mệnh giá, một nguồn lợi tưởng như vô tận cho người sáng lập.

Ở phía bên kia chiến hào, các nhà đầu tư đang hăng hái tiếp nhận phương thức truyền thông đã 
tạo cho họ kỳ vọng rất cao vào vận hành mà không hề biết rằng, tất cả lợi ích chỉ sinh ra trên một lượng tài sản hữu hạn, với mức lợi nhuận hữu hạn. Càng nhiều pháp nhân mới ra đời để chia sẻ cái khối lợi nhuận hữu hạn do thị trường mang tới ấy, giá trị trên mỗi cổ phiếu sẽ càng suy giảm nhanh chóng. Vào tháng 2/2007 cổ phiếu giao dịch 65.000-68.000 VNĐ thì vào tháng 7/2007, con số đó là 25.000 VNĐ và hầu như không còn tính thanh khoản. Việc "tận dụng quá mức" phương pháp truyền thông vào cảm xúc nóng của số đông nhà đầu tư đã đem lại kết cục không có gì sáng sủa cho cổ phiếu, gây một sức ép lâu dài lên chính HĐQT của công ty. Tổn thương thương hiệu và di họa về áp lực tài chính sẽ rất lâu dài, có thể khóa mọi ngả đường và nỗ lực sau này nếu công ty muốn thực sự trở thành đại chúng với ý nghĩa chính trực và lương thiện.

Nhưng còn nhà đầu tư?

Bản thân phương pháp và mức độ yêu cầu thông tin của nhà đầu tư cũng tác động rất mạnh tới phương pháp và mức độ đáp ứng thông tin của các doanh nghiệp. Nhà đầu tư có một sức mạnh rất lớn là lá phiếu của họ với $\mathrm{HĐQT}$ các công ty đại chúng, nhưng sử dụng lá phiếu này lại là "cái giá phải trả" đối với các nhà đầu tư, trong nhiều trường hợp, ví dụ bán cổ phiếu đi khi giá xuống hay thanh khoản thấp. Như vậy, việc thực thi lá phiếu này xem ra đắt đỏ hơn ta tưởng, khi chỉ xét về lý thuyết.

Chính nhà đầu tư cũng là những người có thể sử dụng và phát triển các phương tiện truyền thông gửi tín hiệu và yêu cầu tới các HĐQT các doanh nghiệp. Một trong cách như thế là tham gia tích cực và tận dụng các phương tiện thông tin có uy tín chuyên môn. Các doanh nghiệp khi đã hiểu rõ vai trò $P R$ và cụ thể là $P R$ cho $I R$ sẽ không thể nhắm mắt nhận lấy cái giá phải trả là bỏ qua các kênh thông tin nghiêm túc có sự đồng thuận và phản biện chất lượng của cộng đồng doanh nghiệp, xã hội và cụ thể nhất là các nhà đầu tư.

Đây cũng chính là chuyện truyền thông tài chính và năm vấn đề nguyên lý như chúng ta vừa thử đặt ra ở trên. Chúng tôi cũng hi vọng các nguyên lý có ích cả cho các tờ báo đang tham gia vào công tác truyền thông tài chính và mong nhận được phản hồi để hoàn thiện các nguyên tắc tốt hơn nữa.

Trong một nỗ lực đủ lớn, chắc chắn việc tham gia tích cực của cơ quan quản lý thị trường như Sở GDCK TP.HCM (HOSE) sẽ trở thành định hướng hữu ích. HOSE hoàn toàn có khả năng phối hợp truyền thông tài chính với các kênh truyền thông kinh doanh hiệu quả, được xã hội lắng nghe, để trợ giúp việc công bố thông tin và hoàn thành trách nhiệm quản trị doanh nghiệp (Corporate Governance) cho các doanh nghiệp đang và sắp niêm yết. Những hệ thống tạo được sự phản hồi tức thời cũng sẽ có xu hướng được chăm sóc tức thời, và là một kho báu của truyền thông hiệu quả mà rất nhiều doanh nghiệp chưa khai thác. Như thế, một xu hướng truyền thông tài chính văn minh và hiệu quả đang dần dần định hình.

Báo chí và các kênh truyền thông có vai trò cực kỳ quan trọng trong bối cảnh như vậy. Vai trò này chỉ có tăng lên chứ không thể bớt đi. 
Báo chí nói riêng và giới truyền thông kinh doanh nói chung có nhiệm vụ xây dựng niềm tin cho thị trường chứng khoán.

Điều kiện quan trọng nhất để thị trường chứng khoán phát triển bền vững là niềm tin (Hoàng, 2006). Đây là thị trường buôn bán loại tài sản đặc biệt: tài sản vốn doanh nghiệp. Loại hàng hóa này có một đặc tính khác các hàng hóa tiêu dùng là nó có chứa sự "sợ hãi."

Theo qui luật hàng hóa thông dụng, khi giá giảm lượng mua có thể tăng lên, để đạt tới mức giá cân bằng mới. Điều này sẽ khác đi khi có sự sợ hãi, nghĩa là khi giá của hàng hóa tài sản vốn giảm, nó gây ra sự sợ hãi và xu hướng giảm thường tiếp tục, kéo theo tính thanh khoản sụt giảm đáng kể. Trên TTCK, cũng như phần lớn các thị trường tài chính khác, niềm tin cực kỳ quan trọng. Niềm tin ấy không tự nhiên sinh ra, mà các thiết chế và sự công bằng với người tham gia quyết định. Để tránh những thiệt hại do biến động gây ra thì cần xây dựng niềm tin qua hệ thống công bố thông tin và các thiết chế quản trị xung đột quyền lợi của người tham gia, chế tài từ đại cổ đông, cổ đông nhỏ, đơn vị kiểm toán, các ban giám đốc và các công ty dịch vụ tài chính. Nói chung trục lợi là việc khó tránh, nhưng giảm thiểu việc trục lơi bằng cách gây thiệt hại không chính đáng của các đối tượng khác là nghĩa vụ của một thị trường; cũng là điều kiện cho phát triển lành mạnh lâu dài.

GS. Andre Farber (Trường đại học Université Libre de Bruxelles) trong trao đổi với Đầu tư Chứng khoán ngày 1/5/2006, cũng đánh giá việc giới đầu tư quốc tế lựa chọn TTCK Việt Nam để đầu tư là cơ hội rất tốt đối với một TTCK còn non trẻ , nhưng quan trọng nhất là cả 2 phía (nhà đầu tư nước ngoài và TTCK) phải xây dựng được sự tin tưởng lẫn nhau, mặc dù vẫn biết, lòng tin không thể xây dựng được ngay trong một sớm một chiều. "Điều tôi mong mỏi cho Việt Nam là nhà đầu tư nước ngoài đến đây với TTCK cùng những cam kết lâu dài, chứ không vì lợi nhuận ngắn hạn. Nhà đầu tư đến Việt Nam để hiểu về TTCK và đầu tư trong tầm nhìn dài hạn", GS Farber (Đầu tư chứng khoán, 2006).

\section{Vai trò Giáo dục cực lớn}

Mức độ tác động mạnh mẽ của truyền thông tới cộng đồng tài chính-đầu tư được tất cả các thành phần tham gia thị trường tài chính ghi nhận. Trong bối cảnh đông đảo nhà đầu tư cá nhân dựa trên cảm xúc để tiến hành các giao dịch chứng khoán, vai trò giáo dục của báo chí càng trở nên quan trọng hơn bao giờ hết. Bảo đảm quyền lợi cho cổ đông, nhà đầu tư nhỏ trên thị trường là yếu tố cơ bản duy trì vận hành ổn định và tăng trưởng thị trường bền vững. Quá trình phổ biến kiến thức tới công chúng đầu tư cơ bản có thể chia thành bốn giai đoạn.

\section{Giai đoạn 1: Tác động kỹ thuật. Các hệ} thống truyền thông phối hợp cung cấp khái niệm cơ bản về chứng khoán, nghiệp vụ và kỹ

SSI là mô hình tốt về Investment Banking. Phải hiểu về mô hình này thì viết mới chính xác và có nét. GS. Goldschmidt (ULB, Bỉ), mất nhiều năm học nghề Investment Banking ở Goldman Sachs trước khi quay lại Bỉ hành nghề và lãnh đạo Banque de Groof, khẳng định: việc hiểu rõ mô hình kinh doanh tài chính không hề đơn giản. 
thuật phân tích trên thị trường. Đội ngũ phóng viên đảm trách chuyên mục chứng khoán hợp tác với những người làm chuyên môn, có nhiều kinh nghiệm thực hành trên thị trường, cung cấp bài viết phân tích và đánh giá hợp lý dựa trên nền tảng kiến thức cơ bản và vững vàng.

Giai đoạn 2: Cảm xúc đầu tư - Quan sát - Cơ hội định giá: mất cân bằng và đối xứng. Khi đã nắm vững các nguyên lý vận động của thị trường, nhà đầu tư bắt đầu thực hiện các quyết định đầu tư dựa trên cảm nhận và quan sát vận động cung cầu trên thị trường. Lúc này, thông tin từ báo chí có hàm lượng nhận định cảm xúc cá nhân và chủ quan cao của người viết sẽ không còn tạo ra tác động lớn tới nhà đầu tư nữa. Hiểu biết căn bản giúp công chúng đầu tư có năng lực tiếp nhận và tiêu hóa thông tin hợp lý, xác định giá trị tài sản vốn trên cơ sở các thông số tài chính-vận hành của doanh nghiệp và các tham số liên quan khác trên thị trường. Trạng thái mất cân bằng trên thị trường nhanh chóng bị xóa bỏ. Các quyết định đầu tư được đưa ra trong điều kiện cân xứng thông tin giữa các tác nhân tham gia giao dịch.

Giai đoạn 3: Quản trị vận hành doanh nghiêp. Giá trị của các tài sản tài chính được đảm bảo bằng hiệu quả vận hành-sản xuất kinh doanh của doanh nghiệp, chủ thể phát hành chứng khoán. Năng lực quản trị tốt là cơ sở để doanh nghiệp duy trì và cải thiện sức cạnh tranh trên thị trường tiêu dùng. Nhà đầu tư hiểu rõ điều này và do đó, khả năng đáp ứng yêu cầu cập nhật thường xuyên và đầy đủ thông tin vận hành từ doanh nghiệp ngày càng được chú trọng. Báo chí, phối hợp với cơ quan điều hành và giám sát thị trường (UBCKNN, Sở Giao dịch chứng khoán) vừa làm tốt nhiệm vụ truyền tải thông tin, vừa định hướng quan tâm và hỗ trợ các tổ chức kinh doanh xây dựng năng lực quản trị và cung cấp thông tin công khai, minh bạch tới công chúng.

Giai đoạn 4: Giá tri gia tăng và sáng tạo. Cùng với hội nhập WTO và xu thế vận động kinh tế thế giới hướng tới "kinh tế sáng tạo," các hoạt động kinh doanh và dịch vụ hỗ trợ trên thị trường chứng khoán không những được tổ chức chuyên nghiệp hơn mà còn tạo cơ hội cho nhiều dịch vụ mới xuất hiện. Phần đa số các công việc trên thị trường tài chính-chứng khoán sẽ do các công ty dịch vụ chuyên môn đảm nhận như công ty chứng khoán, tư vấn tài chính, quản lý tài sản-đầu tư, kiểm toán, pháp lý v.v.. Báo chí và công tác truyền thông cũng không ngoại lệ. Giai đoạn này đòi hỏi phát huy năng lực sáng tạo, mang lại các sản phẩm mới, có giá trị gia tăng ngày một nhiều hơn phục vụ thị trường.

Khó lòng tách biệt các giai đoạn nêu trên. Ở đây, vừa có sự kết hợp đan xen các giai đoạn vừa có yêu cầu hợp tác cao độ giữa các đơn vị báo chí, truyền thông, doanh nghiệp, nhà đầu tư và cơ quan chức năng.

\section{Giáo dục cưỡng bức: cưỡng chế thị trường}

Với vị thế của mình, cộng đồng báo chí và truyền thông cần chủ động xác định nhiệm vụ giáo dục của mình với đông đảo nhà đầu tư. Công việc chủ động đưa thông tin tới thị trường là nghĩa vụ, đồng thời, là "áp lực" cưỡng bức công chúng đầu tư tiếp nhận thông tin và tuân theo định hướng. Thứ "quyền lực tự nhiên" này đòi hỏi người làm công tác báo chí, truyền thông không chỉ giỏi về nghiệp vụ, hiểu biết vững vàng kiến thức, mà còn phải có tâm sáng và ý thức tuân thủ chuẩn mực đạo đức nghề nghiệp. 
Trục lợi cá nhân trên thị trường chứng khoán nhờ vị thế đặc biệt của cơ quan báo chí, truyền thông là vấn đề nhạy cảm và nhận được nhiều quan tâm từ cả chính những người trong nghề. Ngày 20/4/2007, hội nhà báo Tp. Hồ Chí Minh kết hợp với tạp chí Nghề báo đã tổ chức Hội thảo "Truyền thông và chứng khoán." Tại hội thảo, câu hỏi "Nhà báo có nên và có thể là nhà đầu tư chứng khoán?" là một nội dung được trao đổi với nhiều ý kiến trái ngược nhau.

Về nguyên lý, vì lợi ích cá nhân, nhà báo chứng khoán đưa thông tin sai lệch hoặc nhận định, đánh giá theo chủ đích kiếm lợi cho bản thân hoàn toàn có thể xảy ra. Thực tế cũng đã có nhiều điều tiếng điều tiếng về những "thông tin có lợi cho ai đó" xuất hiện trên báo, đặc biệt nhắm vào thị trường các cổ phiếu chưa lên sàn, nơi những thông tin tốt xấu được lan truyền với tốc độ phi mã và vô phương kiểm chứng (Ly Lâm, 2007).

Giải pháp khắc phục hợp lý là kết hợp giáo dục ý thức tôn trọng sự thật, đảm bảo tính khách quan của những người làm nghề viết với cơ chế hoạt động cạnh tranh và bình đẳng giữa các đơn vị truyền thông. Báo điện tử Đảng cộng sản ngày 3/10/2007 cũng nêu ý kiến về sự cần thiết phải có được những đơn vị truyền thông kinhh doanh mang tính độc lập cao, chuyên nghiệp với hàm lượng chuyên gia tốt nhằm giúp thị trường dần đi vào minh bạch hóa cao. ${ }^{6}$

Ở nước ngoài, người ta có nhiều cách để ngăn ngừa chuyện này. Đức cấm không cho nhà báo chơi chứng khoán. Còn ở Mỹ, các chủ bút yêu cầu phóng viên viết bài về một công ty phải cam kết không trục lợi từ việc mua bán cổ phiếu của công ty đó và sẽ bị xử lý nghiêm khắc khi có bằng chứng vi phạm. Ngoài ra, cơ chế tự kiểm soát của nghiệp đoàn báo chí các nước này hoạt động rất hiệu quả. Một nhà báo không trung thực sẽ bị vạch trần từ chính các đồng nghiệp của mình, để giữ cho môi trường báo chí được lành mạnh.

\section{Lời cảm ơn}

Tôi trân trọng cảm ơn Ban tổ chức đã tạo điều kiện trình bày và chia sẻ tại Hội nghị. Đối với cá nhân tôi, viết là việc vừa dễ vừa khó. Viết cái mình nghĩ, tức là gặp đâu viết đó thì dễ. Viết cái nhiều người cho rằng có ích thì lúc nào cũng khó.

Tôi chân thành cảm ơn các báo và cơ quan truyền thông hợp tác với SAGA. Tôi cám ơn TS. Nguyễn Anh Tuấn, nhà báo Phạm Oanh (Báo Đầu tư Chứng khoán), cùng các đồng nghiệp Bùi Quang Nam, Lưu Quý Phương và Trần Trí Dũng đã giúp đỡ chuẩn bị bài viết này.

Tài liệu có thể được chuẩn bị kỹ hơn nữa nhưng do hạn chế thời gian nên xin phép được dừng ở đây. Mọi sai sót trong tài liệu này là trách nhiệm cuối cùng của tác giả.

\section{Tài liệu tham khảo}

- Andre Farber trả lời phỏng vấn báo Đầu tư Chứng khoán. Xây dựng lòng tin cho thị trường chứng khoán Việt Nam. Số ngày 1/5/2006.

\footnotetext{
${ }^{6}$ Bùi Quang Nam và Nguyễn Xuân Trường. Tuần lễ vàng của thị trường chứng khoán Việt Nam. Báo điện tử Đảng Cộng sản Việt Nam, ngày 3/10/2007.
} 
- Antweiler, Wener, và Murray Z. Frank. Is all that talk just noise? The information content of Internet stock message boards. Journal of Finance 59, 1259-1293.

- Campbell, John Y., Sanford J. Grossman, và Jiang Wang. Trading volume and serial correlation in stock returns. Quarterly Journal of Economics 108, 905-939.

- DeLong, J. Bradford, Andrei Shleifer, Lawrence H. Summers. Noise trader risk in financial markets. Journal of Political Economy 98, 703-738.

• Lê Vương. Cội nguồn của “bầy đàn.” Thời báo Kinh tế Sài Gòn, 2001.

- Lưu Quý Phương. Bong bóng- Sụp đổ và những tình huống kinh điển. Báo Đầu tư Chứng khoán, số 21 (389), ra ngày 12-3-2007

- Ly Lâm. Giới truyền thông có tác động đáng kể đến TTCK. Doanh nhân Sài Gòn cuối tuần, số 195 , ngày $27 / 4 / 2007$.

- Paul C. Tetlock. Giving content to investor sentiment: The role of media in the stock market. Forthcoming Journal of Finance, 2007

- Peter Watson. Ideas: A history of thought and invention, from fire to Freud. Harper Perennial, New Your, NY 10022, USA, 2006.

- Thục Đoan. Tỉ giá 2003? Thời báo kinh tế Sài Gòn. 2002.

- Thục Đoan. Thiên cơ bất khả lậu! Thời báo kinh tế Sài Gòn. 2002b.

- Trần Trí Dũng. Đi tìm huyền thoại Internet Việt Nam. http://saga.vn/view.aspx?id=6252. SAGA, 17/9/2007.

- Vuong Quan Hoang and Andre Farber. Some new results on anomalies and herd behavior: Vietnam Stock Market. Economic Studies Review (Vietnam), 44(9), 2004.

- Vương Quân Hoàng. Hiệu ứng GARCH trên dãy lợi suất: thị trường chứng khoán Việt Nam 2000-2003. Tạp chí Ứng dụng toán học, số 2(1), 15-30, 2004.

- Vương Quân Hoàng. Văn Minh Làm Giàu \& Nguồn Gốc Của Cải. Nhà xuất bản Chính trị quốc gia Sự thật, Hà Nội, Việt Nam, 2007.

- Vương Quân Hoàng và Nguyễn Châu Hà. Điểm nóng- Quan hệ với cổ đông: Làm sao làm tốt? Doanh nhân Sài Gòn cuối tuần, số 215 , ngày 14/9/2007.

- Vương Quân Hoàng trả lời phỏng vấn báo Hà Nội mới. Niềm tin: Yếu tố quan trọng nhất của thị trường chứng khoán. Số 13389, ngày 28/5/2006.

- Vuong Quan Hoang and Nguyen Van Huu. On the Martingale Representation Theorem and on Approximate Hedging a Contingent Claim in the Minimum Deviation Square Criterion. Some Topics in Industrial and Applied Mathematics, World Scientific Publishing Company, 2007. 